\title{
Systematics and phylogeography of the Mediterranean Helichrysum pendulum complex (Compositae) inferred from nuclear and chloroplast DNA and morphometric analyses
}

\section{Sonia Herrando-Moraira ${ }^{1}$, Pau Carnicero ${ }^{2}$, José M. Blanco-Moreno ${ }^{3}$, Llorenç Sáez ${ }^{2,4}$, Errol Véla ${ }^{5}$, Roser Vilatersana $^{1}$ \& Mercè Galbany-Casals ${ }^{2}$}

1 Institut Botànic de Barcelona (IBB-CSIC-ICUB), 08038 Barcelona, Spain

2 Departament de Biologia Animal, Biologia Vegetal i Ecologia, Universitat Autònoma de Barcelona, ES08193 Bellaterra, Spain

3 Departament de Biologia Evolutiva, Ecologia i Ciències Ambientals \& IRBio Universitat de Barcelona, Av. Diagonal 643, ES-08028 Barcelona, Spain

4 Societat d'Història Natural de les Illes Balears (SHNB). C. Margarida Xirgu 16. ES-07003 Palma de Mallorca, Balearic Islands, Spain

5 UMR AMAP, Université Montpellier 2, 34398 Montpellier, France

Author for correspondence: Sonia Herrando-Moraira, sonia.herrando@gmail.com

ORCID: S.H.M, http://orcid.org/0000-0002-0488-5112

\begin{abstract}
Multiple factors related to complex geomorphological and climatic history, in addition to other biological factors such as hybridization, hinder the definition of some Mediterranean plant groups. The existence of controversial taxonomic treatments, the possible hybridization events involved, and its unknown evolutionary history, make the Helichrysum pendulum complex of sect. Stoechadina an ideal model to understand general processes about Mediterranean plant systematics and evolution. The mosaic range of the complex, which is distributed over several islands and continental areas in the westerncentral Mediterranean Basin, provides an opportunity to investigate how past connections and disconnections between landmasses may have determined the current geographic distribution of genetic variation in this area. The cpDNA region $r p l 32$-trnL intergenic spacer and the nrDNA region ETS were sequenced for 1-8 individuals from each of the 44 populations sampled, covering all taxa and the whole geographic range of the complex. These individuals were analysed together with a broad sampling of the remaining members of sect. Stoechadina. In addition, detailed multivariate analyses of morphological characters were performed for the whole section and for the H. pendulum complex. Considering together distinctive genetic and morphological traits, our species concept is presented and discussed in a context of integrative taxonomy, and five species are recognized within the complex: H. errerae, H. melitense, $H$. pendulum, $H$. saxatile and $H$. valentinum. The first three species are recognizable by qualitative and quantitative morphological traits, and are genetically distinguishable from the rest as shown by the molecular markers analysed. The two last species are reported here to have a putative ancient hybrid origin and are also genetically distinguishable from the rest but morphologically recognisable only by quantitative characters. Phylogenetic relationships shown by nuclear and chloroplast markers, and an intermediate morphology between the two putative parental taxa, point to H. pendulum and H. italicum as the putative parental taxa for $H$. saxatile, and $H$. pendulum and $H$. stoechas as putative parental taxa for $H$. valentinum. In a discriminant analysis of the five species, $97.8 \%$ of all individuals were classified correctly. The high level of haplotype and ribotype diversity observed in North Africa indicates that this region is either the area of origin of the complex or a secondary contact zone. Our results suggest that the complex colonized several islands and migrated through the Gibraltar and Sicilian Straits during phases of low sea level, favoured by local dispersal events that promoted its gradual range expansion. The occurrence of the complex in the Balearic Islands, which have remained isolated even during low sea level phases, could be explained by stochastic long-distance dispersal events.
\end{abstract}


Keywords canonical discriminant analysis; ETS; integrative taxonomy; phylogenetic incongruence; principal component analysis; rpl32-trnL.

Supplementary Material Electronic Supplement (Tables S1, S2; Figs. S1, S2, S3, S4, S5; Appendix S1, S2) and DNA sequence alignments are available in the Supplementary Data section of the online version of this article at http://ingentaconnect.com/content/iapt/tax

Short title Systematics of the Helichrysum pendulum complex

\section{- INTRODUCTION}

There is an increasing interest in understanding the complexity of currently observed genetic patterns and in clarifying the systematics of plant species in the Mediterranean Basin (e.g., ZozomováLihová \& al., 2014). Gene flow among populations, genetic drift and intrinsic biological traits are necessary but not sufficient to explain the distribution and diversity of species (Troia \& al., 2012). Two other factors are decisive for the complex evolution of species: geomorphological history and climate variation (Thompson, 2005). The Mediterranean Basin, which is recognized as one of the global biodiversity hotspots (Myers \& al., 2000; Thompson, 2005), has been heavily influenced by geomorphological and climatic changes since its formation (Woodward, 2009). During the Messinian Salinity Crisis (MSC) (5.96-5.33 Ma; Hsü \& al., 1977), the Strait of Gibraltar closed and the Mediterranean sea level dropped because of intense evaporation. Subsequently, a desert area emerged, allowing the establishing of land bridges between southern Europe and northern Africa (Duggen \& al., 2003) and between some currently isolated areas in the Mediterranean Basin (Beerli \& al., 1996). This area promoted the migration and colonization of new areas by organisms that would otherwise have remained within narrower geographical areas because of reduced dispersal ability. The subsequent refilling of the Mediterranean Basin following the reopening of the Gibraltar Strait (5.3 Ma, beginning of the Pliocene) resulted in the geographical fragmentation of the distribution areas of those organisms which expanded across the Mediterranean Basin (Beerli \& al., 1996). Afterwards, during the Pleistocene glacial periods, the sea level again dropped, and some of the Mediterranean islands reconnected between them or to the mainland, allowing gene flow between populations, e.g., Sicily with other islands in this region such as Malta, and the Aegadian Archipelago (Fernández-Mazuecos \& Vargas, 2011; Lo Presti \& Oberprieler, 2011). These recurrent connections and disconnections of landmasses in Europe and Africa have been considered important modulators of the phylogeography across the region (Nieto-Feliner, 2014). One of the modulators are straits such as the Strait of Gibraltar and the Sicilian Channel, which have played alternative roles as a bridge or a barrier to dispersal, allowing migration and diversification processes, respectively (Lavergne \& al., 2013). While for many plant species straits have caused significant genetic differentiation (Fiz \& al., 2002; Rubio de Casas \& al., 2006; Terrab \& al., 2008), different studies have also documented gene flow between populations on both sides of straits (Ortiz \& al., 2007; Guzmán \& Vargas, 2009; Fernández-Mazuecos \& Vargas, 2011; Lo Presti \& Obeprieler, 2011).

The complex taxonomic problems found in some Mediterranean plant groups are hypothesised to be due to the effects of the environmental factors named above, related to geomorphological and climatic history, but also to biological factors such as hybridization (e.g., Koch \& al., 2016). In recent decades, taxonomy has undergone a renaissance with the application of DNA methods in addition to the traditional morphology-based comparisons. The combination of multidisciplinary data for species delimitation has been termed "integrative taxonomy" (Dayrat, 2005; Schlick-Steiner \& al., 2010). Species limits proposed by morphological taxonomy (iterative taxonomy; Yeates \& al., 2010) may be verified by independent information provided from multiple and complementary perspectives, such as phylogeography, population genetics or ecology. The application of integrative taxonomy has proven useful to resolve conflicting taxonomic treatments of complex Mediterranean groups of species (e.g., Koch \& al., 2016). 
The Helichrysum pendulum aggr. (Greuter, 2006+) (Gnaphalieae, Compositae) is a complex of closely related shrubby or sub-shrubby species in sect. Stoechadina (DC.) Gren. \& Godr. (Galbany-Casals $\&$ al., 2006a). The taxa in the complex are distributed among several islands and continental areas across the western-central Mediterranean region. They grow within a wide altitudinal range $(0-1850 \mathrm{~m})$ and inhabit diverse habitats such as limestone rock crevices in mountain areas, maritime cliffs or scrubland formations. Morphological discontinuities found across the fragmented distribution area have led to the recognition of numerous taxa at specific and infraspecific levels by several authors (Nyman, 1879; Fiori, 1927; Clapham, 1976; Pignatti, 1982). There are numerous alternative taxonomic treatments, and the most recent ones vary from the recognition of only two (Galbany-Casals \& al., 2006a) to nine species (Greuter, 2006+). Some of the analytical treatments focused on a specific geographical area and therefore could not capture the complete morphological variation of the complex (e.g., Clapham, 1976; Pignatti, 1982; Scialabba \& al., 2008), whereas others were comprehensive (Greuter, 2006+). However, none provided a detailed analysis of the morphological data, an explanation of the adopted species concept, or in some cases (Greuter, 2006+; Scialabba \& al., 2008) even an identification key.

Galbany-Casals \& al. (2006a) provided a detailed taxonomic treatment of the entire sect. Stoechadina, in which the Helichrysum pendulum complex was reduced to two species that were clearly distinguishable based on qualitative characters: Helichrysum errerae Tineo, which is endemic to 120 Pantelleria Island, was characterized by herbaceous outermost involucral bracts that are completely or partially covered with a dense indumentum. Helichrysum pendulum (C. Presl) C. Presl (as H. rupestre Raf.), a widely distributed species that included most of the taxa previously described in the complex, was characterized by papery and glabrous outermost involucral bracts. After studying numerous specimens from the entire range, as well as the types of all involved taxa, these authors concluded that the extensive morphological variability in several traits within $H$. pendulum did not follow a clear pattern of correlation, or it presented a high level of overlap among the taxa recognised in other treatments. Overall, these authors considered that the absence of qualitative characters would not allow the unequivocal identification of many specimens, preventing the recognition of most previously proposed taxa.

However, the study conducted by Galbany-Casals \& al. (2006a) had several shortcomings. First, it did not include a multivariate analysis of morphological variation, and the continuous variation in quantitative characters received little attention. Second, the number of studied specimens in some taxa was very limited and only based on herbarium specimens (e.g., Helichrysum melitense (Pignatti) Brullo, Lanf., Pavone \& Ronsisv.). Additionally, the study did not include molecular data. Finally, although morphologically intermediate specimens between several pairs of species were documented-some of them were derived from current hybridization and others apparently from an ancient hybridization-it was not clearly stated whether, and in which cases, specimens originating from hybridization should be considered to constitute species.

The last point is crucial, given that the impact of hybridization on the evolution of Helichrysum Mill. has recently been highlighted (Galbany-Casals \& al., 2012, 2014). On the one hand, hybridization followed by backcrossing with parental taxa is currently occurring between clearly different species. This phenomenon has been identified in the field by the occurrence of occasional morphologically intermediate specimens that grow in the vicinity of both putative parental species (Galbany-Casals \& al., 2006a, 2012; and M. Galbany-Casals and L. Sáez pers. obs. in Mallorca, Sardinia, Ibiza, Crete and Rhodes). In particular, current hybridization events between two species of different sections and backcrossing of hybrids with parental taxa have been demonstrated in a combined study that included multivariate analyses of morphological traits and molecular data (Galbany-Casals \& al., 2012).

On the other hand, historical or past hybridization events probably also occurred repeatedly, as evidenced by molecular studies of the genus focused on phylogeny and biogeography (Galbany-Casals \& al., 2009, 2014). Past hybridization events can sometimes have been the origin of entire lineages, as observed for the entire Mediterranean-Macaronesian-Asiatic clade of Helichrysum, which has been postulated to have originated by allopolyploidy (Smissen \& al., 2011; Galbany-Casals \& al., 2014). Additionally, past hybridization events have been proposed to explain the origin of certain taxa. In particular, $H$. valentinum Rouy, a member of the $H$. pendulum complex from the eastern Iberian Peninsula, has been suggested to have an ancient hybrid origin between $H$. pendulum and $H$. stoechas (L.) Moench (Galbany-Casals \& al., 2006a). This hypothesis was based on the morphologically intermediate 
status between these two species although $H$. pendulum currently does not grow in the distribution area of $H$. valentinum. However, $H$. valentinum grows together with $H$. stoechas, with which it probably also hybridizes (M. Galbany-Casals, pers. obs.). The complexity of this case has not been satisfactorily resolved. To date, contemporary or historical hybridization within the H. pendulum complex or with other taxa of sect. Stoechadina has not been explored using molecular and morphometric data.

For this study, we performed extensive sampling of the whole Helichrysum pendulum complex.

\section{MATERIALS AND METHODS}

Sampling strategy. - We collected 44 populations belonging to all taxa described within the $H$. pendulum complex (as delimited in Greuter, 2006+) and covering their entire distribution ranges (see Figs. 1B, 2A; Electr. Suppl.: Table S1). To take into account all possible existing taxa in the complex, we initially considered 11 putative different taxa based on the most recent and analytical classifications (Greuter, 2006+; Scialabba \& al., 2008; Mateo \& al., 2013; Xiberras, 2013). With the aim of characterizing the genetic structure and variation across the group, population sampling on a region-wide scale was favoured over within-population sampling, and thus one to eight individuals per population were sampled. Helichrysum stoechas is morphologically very similar to some members of the complex. It does not differ in terms of qualitative characters, and $H$. stoechas and the $H$. pendulum complex can partially overlap in their range of variation of most quantitative characters. However, H. stoechas has not been considered a member of this complex in any recent treatment or flora, undoubtedly because of its less robust habit and different ecological preferences, making it readily distinguishable in the field. Confusion between $H$. stoechas and taxa of the $H$. pendulum complex can only be caused by particular herbarium specimens. Helichrysum pomelianum Greuter was deliberately excluded from this study because it was considered to be part of the morphological variation of $H$. stoechas in Galbany-Casals \& al. (2006b). In addition, 57 specimens belonging to 30 different taxa (26 Helichrysum species, five subspecies and Anaphalis margaritacea (L.) Benth. \& Hook.f.) were included in some analyses to test the phylogenetic relationships and to identify possible hybridization events between members of the $H$. pendulum complex and other species of Helichrysum (see Electr. Suppl.: Table S1). This sampling 
focused on other species of the Mediterranean-Macaronesian-Asiatic clade and, in particular, on members of sect. Stoechadina based on previous studies examining morphology, phylogeny and hybridization (Galbany-Casals \& al., 2006a, 2009, 2012, 2014).

In the morphological analysis, which included several analyses with different aims (see below), we sampled 380 individuals of all taxa of sect. Stoechadina, of which 136 belonged to the H. pendulum complex (see Electr. Suppl.: Appendix S1 for the list of all specimens examined). Given that the main aims of the paper were to unravel the evolutionary history and phylogeographic patterns of the $H$. pendulum complex, and to infer the putative ancient hybrid origin of some of the taxa, but not to explore the existence of ongoing hybridization between species of the $H$. pendulum group and other species of sect. Stoechadina, occasional morphologically intermediate specimens were not included here. The study of current hybridization would require specific attention in a separate work.

DNA extraction, amplification and sequencing. - Leaf material was collected in the field and immediately dried in silica gel. Total genomic DNA was extracted following the CTAB method of Doyle \& Dickson (1987) as modified by Cullings (1992) and Tel-Zur \& al. (1999). The quantity of each DNA extraction was checked using NanoDrop-1000 (Thermo Scientific, Wilmington, DE, USA), and the quality was evaluated on a $1.2 \%$ agarose gel.

Amplification and sequencing of the ETS region was performed using the forward primer ETS1f (Linder \& al., 2000) and the reverse primer 18S-ETS (Markos \& Baldwin, 2001); for rpl32-trnL, the forward primer rpl32F and the reverse primer $\operatorname{trnL}^{(\mathrm{UAG})}$ (Shaw \& al., 2007) were used. Polymerase chain reaction (PCR) amplifications were conducted using the reaction mixture described by Barres \& al. (2011). The profiles used for amplification were as described by Galbany-Casals \& al. (2009, 2010). Nucleotide sequencing was performed at "Parque Científico de Madrid" on an ABI 3730 DNA analyser (Applied Biosystems, Foster City, California, USA) or at the DNA Sequencing Core, CGRC/ICBR of the University of Florida on an ABI 3730xl DNA analyser (Applied Biosystems). In total, 253 rpl32-trnL sequences and 202 ETS sequences were included in this study, of which 229 and 175, respectively, were new (see Electr. Suppl.: Appendix S2 for accession numbers).

Network representation and phylogenetic analyses. - The sequences were edited and aligned by hand using Chromas v.2.0 (Technelysium, Tewantin, Australia) and MEGA v.6 (Tamura \& al., 2013). Data matrices are available in the Supplementary Data section of the online version of this article at http://ingentaconnect.com/content/iapt/tax.

The rpl32-trnL and the ETS datasets included, respectively, 216 and 159 specimens belonging to the $H$. pendulum complex. Regions that were rich in poly-T and poly-A were manually excluded, as well as other regions with an ambiguous alignment. In the case of ETS, as previously reported by Conesa \& al. (2012), we found several sequenced specimens with intraindividual polymorphisms (i.e., double peaks) that were coded as ambiguous characters between the two corresponding nucleotides. To consider this variation in the analyses, we used the program Phase v.2.1 (Stephens \& al., 2001), which has been proven a useful tool in other studies (e.g., Ronikier \& al., 2012). This software allows the inference of different coexisting alleles per individual. However, as a limitation, it assumes that a maximum of two alleles are present in one individual. This is not necessarily the case for ribosomal DNA, which has multiple copies in the genome. The ETS dataset was composed of 159 specimens of the $H$. pendulum complex together with 36 specimens representing the remaining species of sect. Stoechadina. The web tool Seqphase (http://seqphase.mpg.de/seqphase/) was used to generate the Phase input files from the fasta sequence alignments and later to convert the Phase output files back into fasta. Using this ETS dataset and the rpl32-trnL dataset, a network of ribotypes/haplotypes was constructed using the statistical parsimony algorithm (Templeton \& al., 1992) implemented in the TCS v.1.21 software (Clement \& al., 2000) with $95 \%$ confidence limits. In these analyses, for both markers, indels were coded as discrete characters using the modified complex indel coding method implemented in SeqState v.1.4.1 (Müller, 2006).

Phylogenetic relationships among the different haplotypes and ribotypes of the complex found in the TCS analyses were inferred separately using four additional species in the case of $r p l 32-\operatorname{trn} L-H$. arwae J. R. I. Wood, H. marginatum DC., H. monogynum B. L. Burtt \& Sunding and H. montanum 
260 DC. - and two species in the case of ETS- $H$. gossypinum Sch. Bip. and H. orientale (L.) Gaertn.which were used as outgroup taxa based on previous studies (Galbany-Casals \& al., 2014). With these two datasets - dataset 1 (rpl32-trnL) and dataset 2 (ETS) - Bayesian inference (BI) and Maximum Parsimony (MP) phylogenetic analyses were performed separately. Bayesian inference analyses were conducted with MrBayes v.3.1.2 (Ronquist \& Huelsenbeck, 2003). The best-available model of molecular evolution was selected using the Akaike information criterion as implemented in jModel-Test v.0.0.1 (Posada, 2008). For rpl32-trnL and ETS, the best fitting models were GTR+G and GTR+I+G, respectively. In accordance with the MrBayes manual, we used the restriction model (F81) for the indel partition of both regions. Two simultaneous and independent analyses of four Metropolis-coupled Markov chains were run for 5 million generations, starting from different random trees and saving one every 500 generations. After checking the analysis performance and the effective sample size values (ESS) with Tracer v.1.6.0 (Rambaut \& al., 2013), the first $25 \%$ of the trees of each analysis were discarded (burn-in). A 50\% majority-rule consensus tree was computed with MrBayes for the remaining trees and was visualized with FigTree v.3.1 (Rambaut, 2009). Maximum parsimony bootstrap analyses (Felsenstein, 1985) were performed with PAUP v.4.0b10 (Swofford, 2002) with 1000 replicates, random taxon addition with 10 replicates, and no branch swapping. Parsimony uninformative characters were excluded to standardize the parsimony statistics.

Geographic structure analyses. - The geographic structure of genetic variation was assessed by analyses of molecular variance (AMOVA) following the approach of Excoffier \& al. (1992) using the programme Arlequin v.3.5.1.2 (Excoffier \& al., 2005). AMOVAs were performed at different hierarchical levels: (1) treating all populations as a single group to determine the percentage of variation between and within populations; (2) dividing populations into two groups: the western group (Majorca, Ibiza, Vedranell, Es Vedrà, Alicante, Gibraltar, Morocco and Algeria) and the central group (Sardinia, Marettimo, Pantelleria, Malta), to determine the percentage of variation accounting for differences between the western and central groups, between populations within groups and within populations; and (3) grouping populations according to smaller geographical areas, mostly corresponding to islands or areas showing discontinuity with others (Majorca, Imperialet, Ibiza, Vedranell, Es Vedrà, Alicante, Gibraltar, Morocco, Algeria, Sardinia, Sicily, Marettimo, Pantelleria and Malta) to determine the percentage of variation attributable to differences between the geographical groups, between populations within groups and within populations. The significance levels of the variance components were obtained by a nonparametric test using 1023 permutations. Phylogeographical structure was also investigated by the Bayesian clustering method implemented in BAPS v.6.0 (Corander \& al., 2008), choosing a spatial clustering algorithm with an unlinkage model among polymorphic sites, and a mixture analysis of individuals with geographic information. We ran 10 replicates from each of the nine simulations from $K=$ 2 to $K=10$. The most likely $K$ was chosen according to the highest $\log$ marginal likelihood [log (ml)] values. We used Barrier v.2.2 (Manni \& al., 2004) to identify where possible barriers to gene flow between $H$. pendulum populations could exist. Monmonier's maximum difference algorithm was applied on Nei genetic distances (Nei, 1972) obtained from GenAlEx v.6.5 (Peakall \& Smouse, 2012). Geographical coordinates of populations were used to obtain a Voronoï tessellation of the study area, on which the five strongest putative barriers were delineated.

Phylogenetic relationships with other species of the genus and the effects of hybridization. - We also aimed to examine the phylogenetic relationships between the $H$. pendulum complex and other species of the genus and to identify possible ancient hybridization events. To achieve these goals, the different haplotypes and ribotypes found in the H. pendulum complex were added to a broader sampling of congeneric species of rpl32-trnL (dataset 3) or ETS (dataset 4) sequences. Taxa were selected based on previous work (Galbany-Casals \& al., 2009, 2014). Dataset 3 included a broad sampling of the Mediterranean-Macaronesian-Asiatic clade, including all species of sect. Stoechadina. Dataset 4 included all ribotypes retrieved with Phase in members of sect. Stoechadina (see above). In both cases, several regions that could not be aligned were manually excluded. Indels were treated as for network representation (see above). With these two datasets, BI and MP analyses were performed as 
312 described above using $H$. argyrosphaerum DC. and $H$. litorale $\mathrm{H}$. Bol. as outgroup taxa for rpl32-trnL, and $H$. gossypinum and $H$. orientale in the case of ETS, based on Galbany-Casals \& al. (2014). The best fitting model of molecular evolution was GTR+G+I for both markers. Additionally, using the same software and conditions described above, we constructed an additional parsimony network for rpl32-trnL that included the 15 haplotypes of the $\mathrm{H}$. pendulum complex and members of the MediterraneanMacaronesian-Asiatic clade. Finally, a neighbour-net (NN) analysis was conducted for ETS using SplitsTree4 v.4.10 (Huson \& Bryant, 2006) with default options including all ribotypes found in the $H$. pendulum complex and in the other species of sect. Stoechadina.

Morphology. - The pattern of morphometric variation within sect. Stoechadina and within the $H$. pendulum complex was evaluated based on 31 characters (Table 1) that were recognized as taxonomically relevant in previous studies (Galbany-Casals \& al., 2006a) or that appeared to be variable during the course of the present study (S. Herrando, pers. obs.). Involucral bracts, florets and indumentum were examined under a ZEISS Stemi DV4 binocular stereoscopic microscope. The characters used for each multivariate analysis, the characters measured, and the type of each character (quantitative, qualitative or semiquantitative) are specified in Table 1 . For the quantitative and semiquantitative characters, the mean of three to five measurements per specimen was used in the analyses.

Exploratory PCAs were performed using individuals as operational taxonomic units. Although some authors discourage the use of non-quantitative data, the basic objective of PCA-to summarize most of the 'variation' that is present in the original set of $p$ variables using a smaller number of derived variables - can be achieved regardless of the nature of the original variables (Jolliffe, 2002). A first multivariate analysis (PCA1) was conducted to examine the morphological variability across the whole of sect. Stoechadina and the morphological distinction of the H. pendulum complex. Based on the results of PCA1 (see Results), an additional analysis excluding $H$. heldreichii Boiss. and members of the $H$. italicum (Roth) G. Don complex was performed (PCA2) in order to reduce the influence of the morphological variability of these taxa in the extraction of the morphological variation of the rest of taxa, which included the $H$. pendulum complex members, $H$. stoechas and $H$. crassifolium. The next analysis (PCA3) was aimed at evaluating the morphological variation within the H. pendulum complex, as well as analysing the consistency of previously recognized taxa. To ease the evaluation of the morphological congruence of the existing taxonomic treatments with PCA, the individuals were labelled in the scatterplots according to predefined groups. We considered the following 11 taxa: $H$. boissieri Nyman, $H$. errerae var. errerae, $H$. errerae var. messerii (Pignatti) Raimondo, $H$. fontanesii Cambess., H. hyblaeum Brullo, H. melitense, H. nebrodense Heldr., H. panormitanum Guss., H. pendulum, H. saxatile Moris and $H$. valentinum. Next, integrating morphological patterns visualized in the PCA3 with information obtained from the genetic variation of the group, we considered that five potential species could be recognized within the complex: $H$. errerae, $H$. melitense, $H$. pendulum, $H$. saxatile and $H$. valentinum. Considering these five taxa, we performed a CDA that, maximizing the discrimination among groups, shows whether predefined groups of species may be distinguishable based on measured characters and which characters contribute to their separation. Binary variables were not used in these analyses given that they were constant within groups. Additionally, $H$. valentinum and $H$. saxatile were analysed with the putative parental species, $H$. pendulum and $H$. stoechas (PCA4), and H. pendulum and H. italicum (PCA5), respectively, to test their plausible hybrid origin based on our molecular results and previous morphological observations (Galbany-Casals \& al., 2006a). Two characters-presence or absence of succulent leaves and synflorescence density-were excluded from these last two analyses because they were not relevant to the taxa involved.

Finally, differences in morphological traits studied in the five taxa accepted here were tested for significance to identify diagnostic characters. First, each morphological character was evaluated to verify the normality requirement. Characters that followed a normal distribution were tested by one-way analyses of variance (ANOVA) in conjunction with Tukey's post hoc multiple comparisons test. The characters that did not meet the normality requirement were log-transformed. When the log-transformed variables were normally distributed, ANOVAs were performed as described above. For characters for which the transformation did not improve the distribution, pairwise Kruskal-Wallis tests were performed 
using Bonferroni correction for multiple comparisons. All comparisons of means were performed using the mean value for each character and specimen. The morphometric study was conducted using SPSS v.17.0 (SPSS Inc., Chicago, IL, USA).

\section{- RESULTS}

Network representation and phylogenetic analyses. - The rpl32-trnL and the ETS sequences for the $H$. pendulum complex ranged from 855 to $870 \mathrm{bp}$ (with a total aligned length of $927 \mathrm{bp}$ including indels) and from 880 to $884 \mathrm{bp}$ (with a total aligned length of $884 \mathrm{bp}$ ), respectively.

A total of 15 cpDNA haplotypes were identified in the $H$. pendulum complex (Figs. 1A, 1B; Electr. Suppl.: Table S1). The most widely distributed haplotype was H1 (65.3\% of all samples), whereas haplotypes H6, H7 and H8 were only found in one individual (Fig. 1A; Electr. Suppl.: Table S1). In most populations, a single haplotype was sampled. Only ten of the 44 populations contained several haplotypes, and seven of them contained one private haplotype. Although some haplotypes were speciesspecific, others were shared by different taxa (Fig. 1B; Electr. Suppl.: Table S1). Three main groups of haplotypes were detected, and they were separated from one another by at least nine mutational steps: H1-H8, H9 and H10-H15 (Fig. 1A; Electr. Suppl.: Fig. S1). In the H1-H8 group, seven haplotypes were derived from one dominant haplotype $(\mathrm{H} 1)$ by one or two mutational steps. In contrast, group H10-H15 contained more divergent haplotypes.

In the case of ETS, among all 159 individuals sequenced, 41 contained additive polymorphic sites. For these individuals a double sequence was generated using the Phase software. Similarly, 10 specimens of the other species of sect. Stoechadina also contained double peaks, and thus several coexisting ribotypes were also recovered with the Phase software. As a result, we finally obtained 200 ETS sequences for the $H$. pendulum complex and 46 sequences for the remaining species of sect. Stoechadina. Among these sequences, 72 nrDNA ribotypes were identified for the $H$. pendulum complex (Fig. 2A), and 38 nrDNA ribotypes were obtained for the other taxa of sect. Stoechadina (Electr. Suppl.: Table S1). In general, there were no shared ribotypes between different taxa of the complex, except for ribotypes R34, R55, R56 and R62 (Fig. 2A; see details in Electr. Suppl.: Table S1, Fig. S2). There were also no shared ribotypes between members of the $H$. pendulum complex and other species of sect. Stoechadina (Electr. Suppl.: Table S1, Fig. S3). Coexisting ribotypes in one individual grouped together in a well-supported clade in $41.5 \%$ of the cases, whereas in the remaining cases the different ribotypes found in one individual were not grouped together (Electr. Suppl.: Table S1, Fig. S2). Noticeably, coexisting ribotypes detected in five individuals of $H$. saxatile were placed in different supported clades: ribotypes R62/R65 detected in one individual of population S1, ribotypes R64/R66 and R62/R66 detected in two individuals from S3, and ribotypes R61/R67 and R63/R66 detected in two individuals from S4 (Electr. Suppl.: Fig. $\mathrm{S} 2$ ). In almost half of the populations (21) intraindividual variation was detected. In 14 populations, a single ribotype was sampled, whereas 30 populations were polymorphic. Only two populations were homogeneous for a private ribotype (R17 from population F11 and R19 from F4). Many ribotypes were found in only one individual (41 ribotypes). The most widely distributed ribotype was R18 (8.5\% of all samples), and only four ribotypes exceeded a frequency of 5\% (R18, R25, R56, R68; Electr. Suppl.: Table $\mathrm{S} 1$ ). To simplify the geographical representation of the ribotypes, they were classified into 18 groups (Fig. 2A) based on the phylogenetic relationships obtained in the BI and MP analyses (Electr. Suppl.: Fig. S2). Three supported clades were recovered in BI and MP phylogenetic analyses: one clade comprised ribotypes R1-R9 ( $\mathrm{PP}=0.97$; Electr. Suppl.: Fig. S2), which are distributed in the central Mediterranean area, specifically in Algeria, Malta and Sicily; a second clade was composed of ribotypes R10-R43 (PP = 0.97; Electr. Suppl.: Fig. S2), which are found in the western part of the Mediterranean Basin, specifically in the Iberian Peninsula, Majorca, Ibiza, Morocco and Algeria; and the third well supported clade comprised ribotypes R54 to R72 from Sicily, Pantelleria and Sardinia (PP = 1, BS = 87; Electr. Suppl.: Fig. S2). The position of the remaining ribotypes (from several locations both in western and central Mediterranean areas) was not resolved. 
Geographical structure analyses. - In the AMOVA, approximately $87.3 \%$ of the rpl32-trnL variation in the $H$. pendulum complex was explained by differences between populations when no regional differentiation was considered, whereas $66.9 \%$ was explained by differences among restricted geographical groups when regional differentiation was hypothesized (Table 2). In the case of ETS, although most of the variation (83.9\%) could be attributed to differences between populations, a significant percentage of the variation was due to differences between the western and central groups (54.6\%), and between more restricted geographical groups (58.2\%), supporting the presence of phylogeographical structure for this marker.

BAPS analyses identified $K=2(\log (\mathrm{ml})=-9745.1)$ for $r p l 32-\operatorname{trn} L$ data and $K=6(\log (\mathrm{ml})=$ -2187.3) for ETS data as the optimal number of genetically homogeneous groups (Figs. 3A, 3B). In the Barrier analysis, the first genetic barrier was inferred between Malta and the remaining populations in the case of rpl32-trnL (Fig. 3C), or between western and central Mediterranean populations in the case of ETS (Fig. 3D).

Phylogenetic relationships with other species of the genus and the effects of hybridization. - In the rpl32-trnL analyses, the phylogram showed a supported MediterraneanMacaronesian-Asiatic clade (BS $=94, \mathrm{PP}=1$; Fig. 1D). It was divided into three subclades (coloured in blue, pink and yellow), which were not correlated with classification at the species, the complex or the sectional level, and none of which had geographical structure. Individuals of the $H$. pendulum complex and $H$. stoechas were found in each of the three subclades, and H. italicum and H. serotinum Boiss. had individuals in two of the three subclades. The statistical parsimony analysis provided the network shown in Fig. 1C, where three main groups, corresponding to the three subclades recovered in Fig. 1D, are coloured. The yellow group is separated from the other two by three mutational steps, and the blue and the pink groups are six mutational steps apart (Fig. 1C). In the ETS analysis, the H. pendulum complex was not monophyletic (Electr. Suppl.: Fig. S3). Furthermore, none of the other species of sect. Stoechadina represented by several individuals was monophyletic (Electr. Suppl.: Fig. S3). In the NN analysis and the phylogenetic analysis (Fig. 2B and Electr. Suppl.: Fig. S3), ribotypes R54-R72 were closely related to $H$. litoreum Guss., H. italicum subsp. italicum, H. italicum subsp. microphyllum (Willd.) Nyman, H. italicum subsp. tyrrhenicum (Bacch., Brullo \& Giusso) Herrando, J.M. Blanco, L. Sáez \& Galbany and H. massanellanum Herrando, J.M. Blanco, L. Sáez \& Galbany, while the remaining ribotypes (R1 to R53) were more related to H. stoechas, H. heldreichii, H. crassifolium and H. serotinum Boiss. Ribotypes from western locations were closely related to the specimens of $H$. stoechas sampled in geographically close localities (Iberian Peninsula and Ibiza), whereas ribotypes from southern Sicily, eastern Algeria and Malta were grouped with specimens of $H$. stoechas from the eastern Mediterranean area (Crete, Greek Islands and Tunisia). Ribotypes found in $H$. valentinum were closely related to $H$. stoechas, one of its putative progenitors. The ribotypes found in $H$. saxatile also were genetically close to one of the plausible parental species, H. italicum.

Morphology. - PCA1 revealed two main groups within sect. Stoechadina: one was composed of members of the H. italicum complex and H. heldreichii, and the other consisted of the H. pendulum complex, H. stoechas and H. crassifolium (Electr. Suppl.: Fig. S4A). Characters that mainly contributed to the separation of these two groups on the first axis (38.3\% of total variance) were width of the outermost involucral bract and total number of florets per capitulum, both of which were higher in the second group. The second analysis (PCA2) was focused on the second group only. The first axis accounted for $20.7 \%$ of the total variation, and the second axis accounted for $14.3 \%$. In this case, $H$. crassifolium and $H$. stoechas were separated from the $H$. pendulum complex mainly due to higher synflorescence length values and the presence of succulent leaves in $\mathrm{H}$. crassifolium and leaves with a denser glandular indumentum on the abaxial side in H. stoechas (Electr. Suppl.: Fig. S4B).

In the PCA3 analysis, the first axis accounted for $16.4 \%$ of the total variation and the second axis accounted for $16.2 \%$. Although these values may look low, they are well above the limits computed by the broken stick rule, which mark the lower limit below which a given axis should be considered to explain random variation (in this case, for the given number of variables: $13.0 \%, 9.8 \%, 8.2 \%$, and $7.1 \%$ 
for the first four axes). The graphical representation (Fig. 4A) showed a main cloud with a broad range of variation and four satellite units. The central cloud was formed by specimens of several taxa- $H$. boissieri, $H$. errerae var. messerii, $H$. fontanesii, $H$. hyblaeum, $H$. nebrodense, $H$. panormitanum and $H$. pendulum — with a large amount of overlap. Around this main cloud, four different entities were observed that corresponded to $H$. errerae var. errerae, $H$. melitense, $H$. saxatile and $H$. valentinum. Considering all combinations of the first four axes, $H$. melitense and $H$. errerae var. errerae were recovered as well separated taxa, whereas there was more overlap among the remaining three taxa $(H$. saxatile, $H$. valentinum and $H$. pendulum; Electr. Suppl.: Fig. S5).

The CDA plot showed that the individuals in the H. pendulum complex were distributed in three main clouds (Fig. 4B). One was composed of the specimens of $H$. errerae, constituting the most differentiated group, which was isolated from the remaining specimens along the first axis accounting for $66.2 \%$ of the total variation. The characters that correlated with the first canonical axis and were thus responsible for the separation of $\mathrm{H}$. erreae were mostly outermost involucral bract texture, number of hermaphroditic florets per capitulum and width of the outermost involucral bract. The following cloud, which differed noticeably from the others along the third axis (explaining 12.3\% of variation), was composed of individuals of $H$. melitense, and features that contributed to its differentiation were capitulum width, capitulum length and capitulum length/capitulum width. The remaining individuals of the complex were grouped in a third group composed of H. saxatile, H. valentinum, and H. pendulum, among which the latter showed the highest intragroup variation. Although these species showed some overlap, they were distributed along the second axis, which correlated with the total number of florets per capitulum, capitulum width and capitulum length/capitulum width. However, this axis only accounted for $13.8 \%$ of the total variance. The total percentage of correctly classified individuals in these five predefined groups was $97.8 \%$. All $\mathrm{H}$. errerae and $\mathrm{H}$. melitense individuals were correctly classified, whereas the percentages of correctly classified specimens for the other taxa were: $92.3 \%$ for $H$. saxatile, 96.4\% for $H$. valentinum and $98.8 \%$ for $H$. pendulum. Misclassified specimens of $H$. saxatile and $H$. valentinum were classified as $H$. pendulum, and misclassified specimens of $H$. pendulum were classified as $H$. valentinum.

In PCA4, the first principal component showed that $H$. valentinum was placed in an intermediate position between $H$. pendulum and $H$. stoechas in terms of their scores for that component, although with a considerable degree of overlap among them (Fig. 5A). Helichrysum saxatile displayed a similar morphological transition, located between $H$. pendulum and $H$. italicum in PCA5 along the first component (Fig. 5B). However, in that case, H. saxatile was clearly placed closer to one of its putative parents, H. pendulum.

Finally, the comparison of means (Electr. Suppl.: Table S2) showed that H. errerae differed significantly $(p<0.05)$ from the other taxa by having narrower outermost involucral bracts that are completely to partially herbaceous and tomentose rather than papery and glabrous. Helichrysum melitense has succulent leaves - unlike the remaining species within the complex - and wider innermost involucral bracts. Helichrysum saxatile showed significant differences in comparison to the others, excluding $H$. errerae, with fewer pistillate and hermaphroditic florets per capitulum and shorter outermost involucral bracts. Regarding $H$. valentinum, a higher density of glandular hairs on the abaxial side of the leaves and fewer capitula per synflorescence accounted for most of its differentiation from the other taxa. Finally, $H$. pendulum showed the greatest variation for a greater number of the characters analysed, although that species is characterized by a less dense eglandular indumentum on the adaxial side of the leaves compared with $H$. melitense and $H$. saxatile, and a larger number of involucral bracts per capitulum than H. valentinum.

\section{- DISCUSSION}

Phylogeographic history of the Helichrysum pendulum complex. - Our results revealed high values for haplotype (4) and ribotype (21) diversity in northern Africa, together with a large number of private haplotypes (3) and ribotypes (19), potentially supporting a northern Africa origin of the 
complex (Figs. 1B, 2A; Electr. Suppl.: Table S1). Sicily standed out to be the second region with high levels of haplotype (5) and ribotype (14) diversity, but haplotypes from Sicily belong all to only one of the three main groups retrieved by cpDNA data, in contrast with the haplotypes found in northern Africa, that correspond to the three different groups (Fig. 1A, coloured groups/clades in Figs. 1C, 1D). Previous studies have strongly suggested an African origin for the whole Mediterranean-Macaronesian-Asiatic clade of Helichrysum-including sect. Stoechadina and the H. pendulum complex-ca. $5 \mathrm{Ma}$ ago (Galbany-Casals \& al., 2009, 2014). Despite this evidence, the resolution obtained in the present study in both the nrDNA and the cpDNA phylogenetic trees is not sufficient to infer the geographic origin of the H. pendulum complex with confidence (Electr. Suppl.: Figs. S1, S2). In addition, it must be noted that other authors, such as Petit \& al. (2003), have demonstrated that the highest diversities can represent contact zones rather than areas of origin. In fact, this may be, at least in part, the case for the H. pendulum complex, given that Moroccan and Algerian populations are placed in an area with high reticulation in the NN graphic (Fig. 2B).

In the unique dated phylogeny including Mediterranean Helichrysum, the clade comprising the whole Mediterranean-Macaronesian-Asiatic clade of Helichrysum and the genus Anaphalis had a divergence time estimation of 7.04 (5.45-8.89) Ma (Nie \& al., 2016). This was the closest supported dated node to sect. Stoechadina clade, which is included within the Mediterranean-Macaronesian-Asiatic clade and would then be younger. However, no members of the H. pendulum complex were included in this work. For this reason, the temporal origin of the $H$. pendulum complex cannot be determined with precision at the moment. With this approximate temporal framework, the ancestors of the complex could have expanded across the western and central Mediterranean regions during times of reduced distances between islands and continental landmasses, either during the MSC or the Pleistocene glaciations. Establishment of the Mediterranean climate with dry summers (3.2 Ma) and Quaternary oscillations with glacial and interglacial stages (from 2.3 Ma to present) may also have promoted diversification driven by isolation in reduced areas, causing allopatric speciation (e.g., Blanco-Pastor \& al., 2012). Additionally, long-distance dispersal events, favoured by the putative excellent dispersal ability of the tiny achenes $(\sim 1$ $\mathrm{mm}$ ), are the most plausible explanation for the complex expansion to areas isolated by the sea, e.g., the Balearic Islands, which have remained isolated since the opening of the Gibraltar Strait (5.3 Ma; Thompson, 2005). The maintenance of this sea mass along the longitudinal axis of the Mediterranean Basin, even during Pleistocene glaciations, caused east-west phylogeographical breaks, which have been detected in many plant groups (Nieto-Feliner, 2014). The H. pendulum complex is one of these cases, as supported by nrDNA data (Fig. 3D). A moderately high percentage of the variation was observed between the western and central groups (54.6\%; Table 2) which share a small number of ribotypes (Fig. 2A; Electr. Suppl.: Table S1). The general distribution of ribotypes revealed a high level of genetic similarity between plants from geographically close localities (Fig. 2A), suggesting an increased probability of genetic exchange among neighbouring populations. A similar pattern was also detected in a phylogeographic study of the Mediterranean H. italicum (Galbany-Casals \& al., 2011), for which the importance of gene flow and genetic affinities among neighbouring populations was highlighted. A high level of genetic differentiation between populations found in the AMOVA (87.3\% for $r p l 32-\operatorname{trn} L, 83.8 \%$ for ETS, Table 2) is likely a consequence of the habitat of these species, given that strong discontinuities between cliff areas contribute to progressive reproductive isolation between populations (Thompson, 2005).

Both markers revealed a strong genetic differentiation of the Maltese populations (considered here as H. melitense), which are characterized by the presence of an exclusive haplotype (H15) separated by seven mutational steps from the closest haplotype (Fig. 1A) and a unique set of ribotypes (R1 and R2, Fig. 2). Additionally, the first genetic barrier for cpDNA was detected between Malta and the remaining populations (Fig. 3C). These results are consistent with the detection of unique haplotypes in Maltese populations of Anthemis secundirramea Biv. (Lo Presti \& Oberprieler, 2011). Our results could suggest an ancient colonization of Malta by seeds, followed by genetic drift due to the long isolation of the archipelago from other regions. The NN graphic (Fig. 2B) and the supported clade recovered from the nrDNA data $(\mathrm{PP}=0.97$; Electr. Suppl.: Fig. S2) revealed genetic affinities between the H. pendulum complex populations from southern Sicily, Algeria and Malta. The affinities between the Maltese and the Sicilian flora and fauna have been well documented (Junikka \& al., 2006) and have been attributed to 
gene flow during Quaternary glaciations when the sea level fell. Currently, H. melitense remains restricted to the western cliffs of Gozo Island, covering an area of less than $25 \mathrm{~km}^{2}$, and they are probably extinct from Malta Island (Sciberras \& Sciberras, 2009).

In contrast to the high genetic differentiation of $H$. melitense, we observed low levels of genetic diversity in $H$. errerae populations from Pantelleria, in agreement with the recent emergence of Pantelleria Island dated to 114000 years ago (Wallmann \& al., 1988), entailing a recent origin for this taxon that probably resulted from a long-distance seed dispersal event. Since its formation, Pantelleria has never been connected to Sicily or Tunisia. However, during the Last Glacial Maximum (19,000-22,000 years ago; Yokoyama \& al., 2000), Pantelleria was separated from Sicily only by a narrow strait (Lo Presti \& Oberprieler, 2011), which could have favoured gene flow between Sicily and the Pantelleria populations. In fact, the phylogenetic affinities of $H$. errerae ribotypes to one $H$. pendulum ribotype detected in southern Sicily (R70) (Fig. 2) suggest a Sicilian origin for H. errerae. However, the two exclusive ribotypes detected in Pantelleria (R68 and R69) indicate the current genetic isolation of these populations, in agreement with a notable morphological differentiation from $H$. pendulum and a local adaptation to distinct habitat conditions, i.e., volcanic rocks rather than limestone substrates (M. GalbanyCasals, pers. obs.).

The geographic proximity of landmasses on both sides of the Strait of Gibraltar appears to have played a significant role allowing the genetic exchange between populations in the $H$. pendulum complex. In particular, our results show a haplotype (H10) that is shared between populations on both sides of the strait (Fig. 1B), suggesting the occurrence of gene flow as described for other plant groups (e.g., Ortiz \& al., 2007; Arroyo \& al., 2008). These results may indicate an ancient expansion of the H. pendulum complex by seeds across the Gibraltar Strait. Haplotype H10 is an internal haplotype, which led us to support this plausible scenario. Although gene flow has been effective in the past between populations of $H$. pendulum on both sides of the Strait, our data also suggest that dispersal and gene exchange were subsequently hindered, resulting in the recent genetic differentiation of the two populations. In particular, no ribotypes are shared between the Gibraltar (Iberian Peninsula) and Rif (Moroccan) populations, indicating a lack of pollen or seed exchange. Moreover, the Gibraltar population contains an exclusive haplotype (H11) that is not present in the Rif population, whereas the Rif population contains five different ribotypes, four of which are exclusive to that population. The exclusive markers found in both populations indicate that they have been sufficiently isolated to become differentiated from one another and from surrounding populations on their side of the Strait. This pattern resembles the one recovered for Quercus ilex L. (Lumaret \& al., 2002) and is similar to that of Laurus nobilis L. (Rodríguez-Sánchez \& al., 2008). The genetic differentiation of populations from the Strait of Gibraltar, both from one another and from surrounding populations on the same side of the Strait, has been interpreted to reflect the role of the areas close to the Strait of Gibraltar as a glacial refuge (Rodríguez-Sánchez \& al., 2008).

Regarding the role of the Sicilian Strait, the NN analysis (Fig. 2B) shows a genetic affinity between populations from southern Sicily and eastern Algeria. The larger number of ribotypes found in North African populations (in comparison to Sicilian ones) might indicate the direction of gene flow from 611 Oberprieler, 2011), although this is difficult to assure based on the present data. The genetic similarities 612 between populations in eastern Algeria and southern Sicily could be explained by land connections during 613 the MSC (Rosenbaum \& al., 2002) or by dispersal events. In the latter, both occasional long-distance 614 dispersal (Cowie \& Holland, 2006; Fernández-Mazuecos \& Vargas, 2011) and/or stepping-stone dispersal through emerged islands during low sea level periods (Stöck \& al., 2008) could occur.

Evidence of past hybridization in the Helichrysum pendulum complex. - The lack of concordance between the cpDNA and nrDNA markers, and between the cpDNA and taxa delimitation, is remarkable (Figs. 1, 2). Although the use of a single chloroplast marker may seem somewhat limited, we found a reasonable degree of variability and a complex pattern of variation. For these reasons, incomplete sampling of cpDNA markers does not seem to be the cause of incongruence between cpDNA and nrDNA. In particular, we detected a sharing of — or grouping of closely related — cpDNA haplotypes by different species. Similar patterns have also been detected in other plant groups (e.g., Comes \& Abbott, 2001; Smissen \& al., 2004; Lo Presti \& Oberprieler, 2011; Zozomová-Lihová \& al., 2014). Although selection, 
recombination, homoplasy (convergent evolution) and gene duplication (paralogy) have been reported as possible causes of incongruence between cpDNA and nrDNA data (Wendel \& Doyle, 1998), two evolutionary processes, which are not mutually exclusive, remain the main hypotheses explaining these types of gene incongruences: (1) horizontal transfer of genes via hybridization and introgression (ancient or recent); and/or (2) persistence of ancestral polymorphisms through multiple speciation events (incomplete linage sorting (ILS) or deep coalescence). The distinction between these two processes might represent a problem that is too difficult to resolve analytically, and a widely applicable approach to do this does not yet exist. The sharing of haplotypes among allopatric taxa could be an argument to support retention of polymorphisms rather than hybridization. For example, haplotype H9 from Algeria was grouped with geographically and taxonomically distant specimens of $H$. italicum subsp. tyrrhenicum from Dragonera (Balearic Islands) and H. rubicundum (K. Koch) Bornm. from Iran, with the latter belonging to sect. Helichrysum Mill. (Fig. 1). However, phenomena such as migration and range contraction could also explain this pattern. Additionally, ILS is less likely to occur in plastid compared with nuclear genomes due to its small effective population size.

In Helichrysum, previous work documented a high level of cpDNA variation in a network representation of the haplotypes found in the $H$. italicum complex, in which three markedly distinct groups of haplotypes were detected (Galbany-Casals \& al., 2011). However, that study only included members of the H. italicum complex, thus the possibility that part of such variability could be due to hybridization with other groups was not explored. In the present study, we recovered the same three main groups of haplotypes (Figs. 1C, 1D, three different background colours), each of which was composed of a mixture of taxa. A careful examination of relationships among taxa within each haplotype group can provide some insights into the underlying processes. In most cases, the obtained pattern highlights past hybridization events, as reported for other plant groups (Jackson \& al., 1999; Fehrer \& al., 2007; BlancoPastor \& al., 2012).

The first case of possible past hybridization was detected between populations of the H. pendulum complex and the $H$. italicum lineage (Figs. 1C, pink group; 1D, pink-shaded clade).The present-day set of haplotypes $\mathrm{H} 10-\mathrm{H} 15$ would derive from the $H$. italicum lineage, which would have donated its chloroplast genome and acted as maternal parent. At least three independent chloroplast capture events would have occurred: the first one would explain the presence of haplotypes H10 and H11 in North African and South Iberian populations of $H$. pendulum, with no consequences for the morphological differentiation of these populations; the second one would explain the presence of haplotypes H12-H14 in populations from Sardinia, which are treated here as $H$. saxatile. In this case, the close relationships of ribotypes R60-R67 found in H. saxatile with ribotypes found in members of the H. italicum complex also support this hypothesis (Fig. 2). This relationship is also supported by the morphometric analysis, in which $H$. saxatile showed an intermediate morphology between $H$. pendulum and $H$. italicum (Fig. 5B). The third one would explain the presence of $\mathrm{H} 15$ in populations from Malta, which are considered here as H. melitense. Three factors favour past hybridization events over current gene flow: (1) the haplotypes of $H$. saxatile and $H$. melitense are closely related to certain $H$. italicum haplotypes (Figs. 1C, 1D), but not identical as they are expected to be in case of recent or current gene flow; (2) no ribotypes are shared between $H$. melitense or $H$. saxatile and $H$. italicum and only one ribotype of $H$. saxatile is shared with $H$. pendulum (Fig. 2B; Electr. Suppl: Fig. S3); and (3) Helichrysum saxatile and H. melitense are morphologically differentiated from $H$. pendulum and H. italicum (Figs. 4-6; Electr. Suppl.: Fig S4). These data clearly suggest that chloroplast capture was a past event and was followed by isolation and subsequent genetic and morphological differentiation in the respective islands. Past interspecific hybridization within Helichrysum has been suggested in previous studies (Galbany-Casals \& al., 2009, 2014). The finding that $H$. italicum is not currently present in Malta further supports the hypothesis of past gene flow over current hybridization; as discussed above, both migration or range contraction could explain the possibility of past gene flow between currently allopatric taxa.

A second case of possible past hybridization is that involving the origin of $H$. valentinum. This taxon shows a notable variation in ribotypes. Whereas ribotype R34 is shared with $H$. pendulum, the two divergent ribotype groups R37-R43 and R49-R52 are exclusive to H. valentinum and not shared with any other taxon (Fig. 2A; Electr. Suppl.: Fig. S3), but they are closely related to ribotypes detected in $H$. 
stoechas specimens from the Iberian Peninsula (Fig. 2B; Electr. Suppl.: Fig. S3). These results indicate that $H$. valentinum was most likely derived from multiple ancient hybridization events, with $H$. pendulum and H. stoechas as parental species, as also suggested in a previous study (Galbany-Casals \& al., 2006a) and morphological data presented here (Fig. 6; Electr. Suppl.: Fig. S4). Although one of the detected haplotypes in $H$. valentinum, $\mathrm{H} 1$, is also the most common haplotype in $H$. pendulum, the presence of an exclusive haplotype (H7) and the previously listed exclusive ribotypes indicate a certain current isolation of $H$. valentinum from the parental taxa.

The existence of current hybridization within the $H$. pendulum complex or between its members and other taxa of sect. Stoechadina was not an aim of the present study, and thus was not explicitly addressed. However, it should be noted that lineages of recent hybrid origin could also be prone to contemporary hybridization, as they can maintain gene flow with their parental taxa when no effective and strong reproductive barriers exist between them (Smissen \& al., 2007; Conesa \& al., 2010). Current hybridization between the different species of the $H$. pendulum complex as accepted here is most probably rare given that they are not sympatric at present. However, current interspecific hybridization could be occurring in at least three cases involving a member of the $H$. pendulum complex and other members of sect. Stoechadina. One is H. saxatile that coexists with H. italicum in Sardinia; the second is $H$. valentinum which currently seems to hybridize with $H$. stoechas in coastal populations where both species coexist; and the third is $H$. pendulum that is sympatric with $H$. crassifolium in Majorca. In these three cases, occasional intermediate specimens have been detected in the vicinity, only separated by a few meters, of each pair of species involved (M. Galbany-Casals \& L. Sáez, pers. obs.). There are several factors that support the hypothesis of a hybrid origin of the morphological intermediate specimens: (1) the coexistence of both parental species and the intermediate specimens in the same location (M. GalbanyCasals \& L. Sáez, pers. obs.); (2) the partial overlap in flowering time of the Helichrysum species involved (Galbany-Casals \& al., 2006a); (3) the low specificity of pollinator species observed in Helichrysum that may favour ongoing genetic exchange among species (Gil, 1994); and (4) the apparent lack of postzygotic barriers after interspecific gene flow (Conesa \& al., 2012). Conesa \& al. (2012) studied in detail the morphological and genetic variation of $H$. pendulum and $H$. crassifolium in the Balearic Islands and concluded that the patterns observed - the existence of a continuous and overlapping range in the leaf features that discriminate the two species, and the presence of intragenomic ETS polymorphisms in both species - were mainly caused by ongoing hybridization between them, and possibly with other species as well. In the present study, we have also detected intraspecific ribotype polymorphism within genomes affecting most of the species, where the ribotypes of a given specimen are not closest relative to each other in the nuclear gene tree (Electr. Suppl.: Table S1, Fig. S2).This phenomenon may be evidence of relatively recent interspecific hybridization, as revealed by the shared ribotypes among different species within the complex. However, we found no shared ribotypes between species from the H. pendulum complex and other species of sect. Stoechadina (Fig. 2; Electr. Suppl.: Table S1, Figs. S2, S3). This could be because the occasional intermediate specimens that could have originated from current hybridization were not included in the study, but also because of the intrinsic limitations of the software Phase, that only retrieves a maximum of two alleles in each individual. This potentially could underestimate the amount of variation found in the ribosomal DNA.

Revised taxonomic treatment of the Helichrysum pendulum complex. - The present study sheds light on the delimitation of taxa of the $H$. pendulum complex. It differs from all previous taxonomic treatments in three remarkable aspects: (1) it includes a complete study of numerous specimens from all taxa of the complex, including representatives from the entire distribution area; (2) both morphological and molecular data are provided and analysed in detail; and (3) members of the $H$. pendulum complex are studied together with representatives of all other members of sect. Stoechadina. This comprehensive approach contributes not only to the characterization of the taxa of the H. pendulum complex but also to the interpretation of the evolutionary events underlying their origin.

In the present study, a species is defined in an attempt to fulfil two main criteria: (1) it must be constituted by a population or a group of populations that are morphologically recognizable by a set of common quantitative and/or qualitative traits, simultaneously permitting its differentiation from related species; and (2) its members should have a common origin—including a hybrid origin—and thus be 
genetically closely related to one another and genetically distinguishable from other species. However, it is important to state that these two ideal criteria are difficult to meet in groups with two characteristics, as observed in the $H$. pendulum complex: (1) the group is composed of very closely related taxa, in which morphological variation is sometimes subtle and gradual between taxa; and (2) shows past and present hybridization between species. For these reasons, additional data on the ecology and geographic distribution of the studied populations, gathered over many years of observation of wild populations, provide valuable information for the finally adopted taxonomic treatment.

The proposed taxonomical framework presented here solves a long-standing problem of species identification in the $H$. pendulum complex. With our present proposal, the accuracy of correct assignment of a specimen to one of the five retained species in the $H$. pendulum complex is about $98 \%$ using morphological characters. We provide the characters identified as taxonomically relevant and useful to separate the different taxa recognized here, although a certain overlap of the quantitative features of the data was revealed by the multivariate analyses. The taxonomically valuable characters include the morphology of vegetative traits - eglandular indumentum of the adaxial side of leaves, glandular indumentum of the abaxial side of leaves, and the presence of succulent leaves - and reproductive traitsnumber of capitula per synflorescence, number of pistillate and hermaphroditic florets per capitulum, outermost involucral bract length, width, texture, and eglandular indumentum, and innermost involucral bract width and number of involucral bracts per capitulum. According to these morphological characters and the evidence from molecular data, we recognize five species within the complex: $H$. pendulum, $H$. errerae, $H$. melitense, $H$. valentinum and $H$. saxatile. The degree of differentiation in terms of morphology and molecular data is not equivalent for all them. The first three species are clearly recognizable by qualitative and quantitative morphological traits in multivariate analyses and ANOVAs (Fig. 4; Electr. Suppl.: Table S2, Fig. S5), and additionally they are genetically distinguishable from the rest by nrDNA, cpDNA or both molecular markers (Figs. 1, 2; Electr. Suppl.: Table S1, Figs. S2, S3). Helichrysum valentinum and $H$. saxatile are reported here to have a putative ancient hybrid origin, with $H$. pendulum as one of the parental species involved, and $H$. stoechas and H. italicum as the second parental species involved, respectively. Their hybrid origin probably determines that these two species are only distinguishable by quantitative characters from their parental species, and that a notable degree of overlapping with one or both of them exists (Figs. 4, 5). In these two cases, molecular information provides the clue that points to their recognition at the species level, given that it provides evidence of: (1) their past hybrid origin, (2) the particular species involved in their origin, and (3) their current isolation, evidenced by their genetic differentiation, i.e. the possession of private nrDNA and cpDNA markers. Hereafter, we provide detailed discussion for each case.

Helichrysum pendulum in a strict sense is suggested herein to represent a single polymorphic taxon, which is consistent with Galbany-Casals \& al. (2006a; as H. rupestre DC.). Considering nomenclatural priority (Aghababyan \& al., 2007) and the results obtained, the name $H$. pendulum, based on plants from the Madonie Mountains in Sicily, should be applied to populations of the H. pendulum complex distributed throughout the Balearic Islands, Gibraltar, Morocco, Algeria, Sicily and the Marettimo islet. This species contains several local genetic particularities, mainly in northern Africa, Gibraltar and Sicily (Figs. 1B, 2A). However, these slightly divergent populations could not be distinguished by morphometric data, suggesting that they reflect the phylogeographical history of the species but do not merit taxonomic recognition.

Several investigations have been performed in Sicily to resolve relationships among Helichrysum entities and to clarify their systematics (Pignatti, 1982; Giardina \& al., 2007; Scialabba \& al., 2008). The lack of an assessment of the Sicilian populations in the context of the variation of the entire H. pendulum complex led these studies to report numerous taxa at the infraspecific and/or species level. Here, we evaluated the variation in the whole distribution area of the species complex and increased the number of individuals sampled in comparison to previous work. Our combined results for the molecular and morphological data reflect the inconsistency of distinctive traits that makes the differentiation of most of the previously recognized entities very difficult. Only the populations from mountains of western Sicily (Madonie Mountains) and southern Sicily deserve special attention. Some populations from the Madonie Mountains have been considered a separate taxon restricted to that area and named $H$. pendulum in the treatments proposed by Presl (1826), Gussone (1844), Lojacono Pojero (1889-1908), Greuter (2006+) 
and Scialabba \& al. (2008), independent from other populations from the Madonie Mountains, named $H$. nebrodense, and from populations from the western coastal part of the island, which have been considered as $H$. panormitanum. Scialabba \& al. (2008), using AFLP markers, argued that $H$. pendulum populations were genetically isolated and distant from other Sicilian locations. In the present study, $H$. pendulum shares haplotype $\mathrm{H} 2$ with other mountain populations from Sicily belonging to $H$. panormitanum and $H$. nebrodense, but has an almost exclusive ribotype (R62), only shared with $H$. saxatile but not present in other Sicilian populations (Figs. 1, 2). Helichrysum nebrodense has an exclusive ribotype (R58) but also shares ribotype R56 with other Sicilian populations. Given the low level of genetic differentiation of $H$. pendulum, $H$. panormitanum and $H$. nebrodense, and the lack of morphological characters to distinguish them, we consider all of them to belong to a single species, $H$. pendulum. The taxonomic status of the populations from southern Sicily, traditionally assigned to H. hyblaeum, remains unclear. In this case, we detected genetic singularities, such as the exclusive haplotypes (H3 and H4) and ribotypes (R3, R4, R5, R6 and R70). Scialabba \& al. (2008) found that H. hyblaeum was genetically isolated from the other Sicilian populations. However, this genetically structured pattern of variation is barely reflected in the morphology to allow the differentiation of these populations. Thus, we tentatively do not consider that such southern Sicilian populations deserve taxonomic recognition, although more detailed studies focused on these populations are desirable. In fact, ribotypes detected in $\mathrm{H}$. hyblaeum are closely related to specimens of H. stoechas from Tunisia and Greece (Fig. 2B, Electr. Suppl.: Fig. S3). These results are consistent with previous suggestions concerning possible hybridization between $H$. hyblaeum and $H$. stoechas in southern Sicily (Galbany-Casals \& al., 2006a), or a possible hybrid origin of the former.

The results of the DNA analyses showed that $H$. fontanesii populations (Cambessèdes, 1827; Greuter, 2006+) from the Balearic Islands, Morocco and Algeria are poorly differentiated genetically. Moreover, the absence of marked distinctive morphological characteristics (Fig. 4A) led us to include this taxon within the variable $H$. pendulum. Its separation was originally based on the subglabrous to arachnoid leaves on the adaxial surface, but this is not true for all specimens from the area inhabited by $H$. fontanesii, and this feature can also be seen in some Sicilian specimens. Helichrysum boissieri, which has been described from Gibraltar (Nyman, 1879; Greuter, 2006+), showed genetic differentiation in both markers (Figs. 1B, 2A), but again it could not be morphologically recognized as a distinct species. It is noteworthy that neither $H$. fontanessii nor $H$. boissieri have been recognized in recent local floras, and instead both are treated as $H$. rupestre, a broadly distributed taxon that also includes the Sicilian populations (Valdés \& al., 1987; Bolòs \& Vigo, 1996). Fennane \& Ibn Tattou (1998) indicated that $H$. boissieri is also present in northern Morocco, but that particular population is composed of H. stoechas specimens (Galbany-Casals, pers. obs.).

Helichrysum errerae is supported here as a distinct species restricted to Pantelleria Island and clearly characterized by completely or partially herbaceous outermost involucral bracts that are covered with a dense eglandular indumentum (Fig. 4, Electr. Suppl.: Table S2). These qualitative differences with respect to $H$. pendulum justify its recognition at the species level even in the most synthetic treatments (Galbany-Casals \& al., 2006a). It has also been reported to be distributed in Marettimo islet, with a different variety, H. errerae var. messerii, based on genetic similarities of populations from the two islands detected using AFLPs (Scialabba \& al., 2008). However, here we show that specimens from Marettimo islet are morphologically indistinguishable from $H$. pendulum, which in turn is clearly separated from H. errerae (Fig. 4). Genetically, Pantelleria populations contain two exclusive ribotypes (R68 and R69; Fig. 2) which are closely related to ribotype R72 found in Marettimo islet, in agreement with the findings of Scialabba \& al. (2008), but are also related to ribotype R70 found in H. pendulum.

Another case of island endemism is H. melitense from Gozo Island (Malta). Maltese populations are recognized here as a separate species based on their distinct morphology (Figs. 4, 6) and the high level of genetic differentiation seen in their private haplotype (H15; Fig. 1) and ribotypes (R1 and R2; Fig. 2). These are noticeably different from any other haplotypes and ribotypes in the section. Its taxonomic status has been historically controversial. This taxon was originally described as a variety of $H$. pendulum (sub H. rupestre) by Pignatti (1980) and latter recognized at the species level by Brullo \& al. (1988) only based on its wider leaves relative to those of $H$. pendulum in Sicily. Later, Galbany-Casals \& al. (2006a) considered $H$. melitense a synonym for $H$. rupestre, arguing that leaf width is very variable within Helichrysum species, although minimal material was studied. Here, a more complete morphometric study 
836

837

838

839

840

841

842

843

844

845

846

847

848

849

850

851

852

853

854

855

856

857

858

859

860

861

862

863

864

865

866

867

868

869

870

871

872

873

874

875

876

877

878

879

880

revealed that $H$. melitense leaves are significantly wider than those in other taxa of the complex and noticeably succulent (Electr. Suppl.: Table S2), a trait that was not noticed in previous work based on the study of old herbarium material. Both morphological and molecular data confirm the particularities of the Maltese populations and therefore support the recognition of $H$. melitense.

Helichrysum valentinum has been treated as an independent species (Rouy, 1888), as a subspecies of H. pendulum under different names (Mateo, 2005; Mateo \& Crespo, 2008; Crespo \& Mateo, 2010) or as a synonym of $H$. pendulum (sub $H$. rupestre; Bolòs \& Vigo, 1996). As discussed above, it was considered to be of hybrid origin between H. rupestre and H. stoechas by Galbany-Casals \& al. (2006a), based on the observed intermediate morphological characters between its putative parents. These observations are supported here by molecular data, as discussed above, and by morphological analyses (Fig. 5A, Electr. Suppl.: Fig. S4). The hybrid origin strongly supports its recognition as a species instead of as a subspecies of any of the parental taxa. Helichrysum valentinum is distinct in terms of having fewer capitula per synflorescence than $H$. pendulum (Electr. Suppl.: Table S2), in accordance with the observations of Mateo (2005). Additionally, we found that $H$. valentinum has shorter leaves compared to the remaining species in the complex (Fig. 6; Electr. Suppl.: Table S2), which are not necessarily narrower as suggested by Mateo (2005). Galbany-Casals \& al. (2006a) reported that several intermediate specimens can be observed between $H$. valentinum and $H$. stoechas in coastal localities where the two species coexist, which, as discussed above, could be of recent hybrid origin between the two species.

The populations from central-eastern Sardinia also deserve special attention. These populations were originally described as a separate species that is endemic to Sardinia, H. saxatile (Moris, 1840-1843), as recognized by Clapham (1976), Pignatti (1982), and Baccheta \& al. (2003), mainly based on smaller and narrower capitula and leaves than in H. pendulum (sub H. rupestre). Later, Galbany-Casals $\&$ al. (2006a) considered it synonymous with $H$. rupestre, given that no qualitative characters allowed the separation of the two taxa. Here, we support the taxonomic recognition of $H$. saxatile, despite a certain overlap with the morphological variation of $H$. pendulum in the PCA and CDA analyses (Figs. 4, 5B; Electr. Suppl.: Fig. S4). As suggested in previous investigations, capitula are significantly shorter in $H$. saxatile (Electr. Suppl.: Table S2), and we further discovered a smaller total number of florets per capitulum and shorter outermost involucral bracts (Electr. Suppl.: Table S2). Moreover, the high genetic diversity of Sardinian populations and their genetic differentiation from other populations of the $H$. pendulum complex is noteworthy, with three exclusive haplotypes (H12, H13 and H14; Fig. 1B) and eight exclusive ribotypes (R60, R61, R63, R64, R65, R66, R67 and R71; Fig. 2). This genetic differentiation from other taxa is due, in part and as discussed above, to H. italicum, one of the putative parental taxa involved in its origin. Our morphological analysis (Fig. 5B) supports the hypothesis of a hybrid origin since it revealed a morphological gradient in the Sardinian populations, with varying degrees of similarity to the putative parental species; the appearance of some specimens is similar to $H$. pendulum, while others have smaller and narrower capitula like $H$. italicum. In general, $H$. saxatile is morphologically much more similar to $H$. pendulum than to $H$. italicum. However, as in the case of $H$. valentinum, its hybrid origin strongly supports its recognition as an independent species, and it should not be subordinated at any infraspecific rank under one of its parental species. Helichrysum pendulum does not currently exist in Sardinia, in contrast to $H$. italicum. Current gene flow between $H$. saxatile and $H$. italicum could be still occurring, as suggested by the presence of individuals with intermediate morphological features between these two species in localities where they coexist (Galbany-Casals \& al., 2006a; M. Galbany-Casals and L. Sáez, pers. obs.).

\section{- TAXONOMIC TREATMENT}

Based on the discussion above, the following taxonomic treatment with a standard identification key is presented. Given the hybrid origin of $H$. saxatile and $H$. valentinum, some morphological overlap may exist between each of them and $H$. pendulum. We also provide the habitat requirements and the distribution range for each taxon, and a complete nomenclatural treatment. 
This is an Accepted Manuscript of an article published in TAXoN on August 2017, available online: https://doi.org/10.12705/664.7

\section{Key to the species of the Helichrysum pendulum complex}

1. Outermost involucral bracts $(0.5) 1-1.8(2) \mathrm{mm}$ wide, totally or partially herbaceous, densely tomentose H. errerae

1. Outermost involucral bracts $(0.8) 1.5-3.2 \mathrm{~mm}$ wide, totally papery, glabrous to subglabrous 2

2. Leaves succulent, densely tomentose on both sides; basal and median cauline leaves of flowering and vegetative stems (1.8)2.7-4.7(5.8) mm wide. Capitula 5.7-8 mm long.... H. melitense

2. Leaves not succulent, subglabrous to densely tomentose on the adaxial side, densely tomentose on the abaxial side; basal and median cauline leaves of flowering and vegetative stems (0.6)1-4(7) mm wide. Capitula (4)5-7(8) $\mathrm{mm}$ long

3. Basal and median cauline leaves of flowering and vegetative stems (8.5)12-36(53) mm long, densely tomentose and sparsely to densely glandular on the abaxial side, rarely eglandular. Synflorescences with (5)9-30(53) capitula H. valentinum

3. Basal and median cauline leaves of flowering and vegetative stems $10-70(85) \mathrm{mm}$ long, densely tomentose and eglandular to sparsely glandular on the abaxial side. Synflorescences with (7)12-100(146) capitula

4. Leaves arachnoid-tomentose to densely tomentose on the adaxial side. Capitula 4.5-6.5(7) $\mathrm{mm}$ long, with (20)24-47 florets, 4-13 pistillate and 13-37 hermaphroditic. Outermost involucral bracts

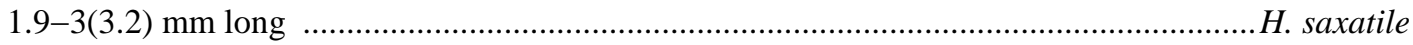

4. Leaves subglabrous to arachnoid, rarely arachnoid-tomentose or tomentose, on the adaxial side. Capitula (4)5-7(8) mm long, with (23)30-74(88) florets, (5)7-24(29) pistillate and (21)25-55(62) hermaphroditic. Outermost involucral bracts $2-4.9 \mathrm{~mm}$ long .H. pendulum

Helichrysum errerae Tineo, Pl. Rar. Sicil. 2: 27. $1846 \equiv$ H. saxatile subsp. errerae (Tineo) Nyman, Consp. Fl. Eur.: 381. $1879 \equiv$ H. saxatile var. errerae (Tineo) Fiori in Fiori \& Paol., Fl. Italia 3: 282. $1904 \equiv H$. saxatile var. errerae (Tineo) Zangh., Flora Italica 1: 695. 1976, comb. superfl. $\equiv$ H. rupestre var. errerae (Tineo) Pignatti in Giorn. Bot. Ital. 113 (5-6): 363. 1980 - Lectotype (designated by Aghababyan \& al., 2007: 1286, superseding the neotype proposed by GalbanyCasals \& al., 2006c: 494): "Helichrysum Errerae Tin., Pantellaria" [manu Tineo], herb. siculum Gussonei (NAP).

Habitat. - Maritime volcanic rocks and cliffs. Altitudinal range: 10-118 m.

Distribution. - Endemic to Pantelleria Island (SW Sicily).

Helichrysum melitense (Pignatti) Brullo, Lanfranco, Pavone \& Ronsisvalle in Giorn. Bot. Ital. 122, suppl. 1: $9.1988 \equiv$ H. rupestre var. melitense Pignatti in Giorn. Bot. Ital. 113 (5-6): 363. 1980 Holotype: Insula Gaulos, Cala Dueira, in rupibus maritimus, 22-IV-1874, Duthie s.n. (FI 001872 !).

Habitat. - Intact limestone coastal cliffs and scree, preferring full sun. Occasionally found along the plateau on top of the cliffs. Altitudinal range: $15-100 \mathrm{~m}$.

Distribution. - Endemic to western cliffs of the island of Gozo and Fungus Rock (Malta).

Helichrysum pendulum (C.Presl) C.Presl, Fl. Sicul.: xxix. $1826 \equiv$ Gnaphalium pendulum C.Presl in J.Presl \& C.Presl, Delic. Prag.: 97. $1822 \equiv$ H. rupestre subsp. pendulum (C.Presl) Arcang., Comp. Fl. Ital.: 376. $1882 \equiv$ H. rupestre var. pendulum (C.Presl) Fiori, Nuov. Fl. Italia 2: 890. 1928, comb. superfl.- Lectotype (designated by Aghababyan \& al., 2007: 1286): "Helichrysum pendulum Pr., Gnaphalium pendulum Pr. del. Pendulum in praeruptis mont. Scalune Nebrodum. ђ Jul. 1817” (PR 616046 photo!). 
= Gnaphalium rupestre Raf., Précis Découv. Somiol.: 41. 1814, nom. illeg. (non. Pourr. in Hist. \& Mém. Acad. Roy. Sci. Toulouse 3: 320. 1788) $\equiv$ Helichrysum rupestre DC., Prodr. 6: 182. 1838, nom. illeg. $\equiv$ H. stoechas subsp. rupestre (Raf.) Maire in Jahand. \& Maire, Cat. Pl. Maroc 3: 751. 1934 - Neotype (designated by Galbany-Casals \& al., 2006c: 492): Palermo, in rupibus calcareis, V, Todaro 551 (PAL 8720!; isoneotypes: FI 001852!, FI 001853!, K 001273168!, P!, PH 1029697 photo!).

= Helichrysum fontanesii Cambess. in Mém. Mus. Hist. Nat. 14: 270. $1827 \equiv$ H. rupestre var. fontanesii (Cambess.) DC., Prodr. 6: 182. $1838 \equiv$ H. stoechas f. fontanesii (Cambess.) Knoche, Fl. Balear. 2: 459. $1922 \equiv$ H. rupestre var. fontanesii (Cambess.) Magallon, Fl. Veg. Alicante: 356. 1972, comb. superfl. $\equiv H$. pendulum subsp. fontanesii (Cambess.) M.B.Crespo \& Mateo in Flora Montiber. 45: 92. 2010 - Lectotype (designated by Rosselló \& Sáez, 2000: 32): Lluch, 20-IV-1825, Cambessèdes s.n. (MPU-KNOCHE MPU 310728!; isolectotype: P!).

= Helichrysum nebrodense Heldr. in Ann. Accad. Aspir. Naturalisti 1: 286. $1843 \equiv$ H. rupestre subsp. nebrodense (Heldr.) Arcang., Comp. Fl. Ital.: 376. $1882 \equiv$ H. rupestre var. nebrodense (Heldr.) Fiori, Nuov. Fl. Italia 2: 672. 1927, comb. superfl. - Lectotype (designated by Aghabyan \& al., 2007: 1286, superseding the neotype proposed by Galbany-Casals \& al., 2006c: 496): "Helichrysum nebrodense? Nob. inedit., in rupibus calcareis prope Isnello, 12 Jun. 1840. Theod. de Heldreich" [manu Heldreich], herb. siculum Gussonei (NAP).

= Helichrysum panormitanum Tineo ex Guss., Fl. Sicul. Syn. 2: $467.1844 \equiv$ H. panormitanum var. angustifolium Tineo ex Guss., Fl. Sicul. Syn. 2: 467. 1844, nom. illeg. 三 Gnaphalium panormitanum (Tineo ex Guss.) Bertol., Fl. Ital. 9: 135. 1853 = H. rupestre subsp. panormitanum (Tineo ex Guss.) Arcang., Comp. Fl. Ital.: 375. 1882 - Lectotype (designated by Aghababyan \& al., 2007: 1286): In rupibus calcareis prope Panormum, scala di Maseddu [manu Tineo], "Tineo" [manu Gussone], herb. Siculum Gussonei (NAP photo!; isotype: FI 001854!).

= Helichrysum panormitanum var. latifolium Guss., Fl. Sicul. Syn. 2: 467.1844 - Lectotype (designated by Galbany-Casals \& al., 2006c: 497, amended by Aghababyan \& al., 2007: 1287): “Elichrysum panormitanum Tin. b. latifolium Guss.!! [scripsit] Grande, 1916”; "Maggio, Bagheria a Capo Zafferano" [manu Gussone], [Gussone], herb. siculum Gussonei (NAP photo!).

= Helichrysum pendulum var. compactum Guss., Fl. Sicul. Syn. 2: 467.1844 - Lectotype (designated by Aghababyan \& al., 2007: 1287): specimen bearing two labels: "Luglio, Madonie", and "6b. Helichrysum pendulum b. compactum Supl. syn. 2 p. 467,Junio, Julio Ђ, in rupibus calcareis montosis." [manu Gussone], herb. siculum Gussonei (NAP).

= Helichrysum pendulum var. laxiusculum Guss., Fl. Sicul. Syn. 2: 467.1844 - Ind. loc.: "Busambra (Tin.), Monte de Cani, Caltavuturo, Vicari, Pizzuta = et in Marettimo".= Helichrysum stramineum Guss., Fl. Sicul. Syn. 2: 467. $1844 \equiv$ H. rupestre var. stramineum (Guss.) Fiori, Nuov. Fl. Italia 2: 672. 1927 - Lectotype (designated by Galbany-Casals \& al., 2006a: 499): Sferracavallo, Tineo, [herb. siculum Gussonei] (NAP photo!).

= Helichrysum boissieri Nyman, Consp. Fl. Eur. 1: 381. $1879 \equiv$ H. rupestre var. boissieri (Nyman) Willk., Suppl. Prodr. Fl. Hispan.: 79. $1893 \equiv$ H. stoechas subsp. boissieri (Nyman) Maire in Jahand. \& Maire, Cat. Pl. Maroc. 3: 751.1934 - Lectotype (designated by Galbany-Casals \& al., 2006c: 494): Gibraltar, in rupibus, V-1837, Boissier s.n. (G 00446427!; isolectotypes: G 00446428!; G-DC G 00470401!, K 001273166!, P!, W 0045868!).

= Helichrysum porcarii Tineo ex Lojac. in Natural. Sicil. 2: 182. 1883 - Lectotype (designated by Aghababyan \& al., 2007: 1287): "Helichrysum porcari Tin., Agosto, Madonie, Salto della Botte, Porcari” [manu Porcari], herb. siculum Gussonei (NAP).

= Helichrysum wickstromii Tineo ex Lojac. in Natural. Sicil. 2: 182. 1883 - Lectotype (designated by Aghababyan \& al., 2007: 1287): "Giugno 49, Elichrysum Wickströmii Tin. ined., Pizzuta" [manu Tineo], herb. siculum Gussonei (NAP). 
= Helichrysum fontanesii var. latifolium Font Quer in Bol. Soc. Esp. Hist. Nat. 20: 148. $1920 \equiv H$. rupestre f. latifolium (Font Quer) O.Bolòs \& Vigo in Collect. Bot. (Barcelona) 14: 103. 1983 Lectotype (designated by Rosselló \& Sáez, 2000: 32): Eivissa, Cala de les Torretes, pr. Sta. Agnès, 29-V-1918, Gros s.n. (BC 30830!).

= Helichrysum rupestre var. messerii Pignatti in Giorn. Bot. Ital., 113 (5-6): 363. $1980 \equiv$ H. errerae var. messerii (Pignatti) Raimondo in Bocconea 20: 11. 2007 - Holotype: Marettimo, in rupibus calcareis maritimis, VI-VIII-1900, Ross 243 (Ross Herb. Sic. 243, Sub. Helichrysum rupestre var. pendulum) (FI 001873!; isotypes: G 00418267!, K 001273169!, P!).

= Helichrysum hyblaeum Brullo in Colloq. Phytosociol. 21: 630. 1995 - Holotype: Valle del f. Irminio, fra Modica e Ragusa, 4-V-1983, Brullo s.n. (CAT 005229; isotypes: FI 001863!, FI 001864!, FI 001865 !).

Habitat. - Limestone rock crevices and maritime cliffs. Altitudinal range: $15-1850 \mathrm{~m}$.

Distribution. - Western-central Mediterranean area: S Iberian Peninsula (Gibraltar) and Balearic Islands (Majorca, Ibiza, Cabrera and Es Vedrà and Vedranell islets), Morocco, Algeria, Sicily and Marettimo islet.

Helichrysum saxatile Moris, Fl. Sardoa 2: 387, t. 82. 1840-1843 E Gnaphalium saxatile (Moris) Bertol., Fl. Ital. 9: 136. 1853, nom. illeg. (non L., Sp. Pl.: 857. 1753) - Lectotype (designated by Arrigoni \& al., 1980: 245): Baunei ad rupes, s.d., Moris s.n. (SASSA photo!).

Habitat. - Limestone rock crevices, rocky slopes and cliffs. Altitudinal range: $317-1000 \mathrm{~m}$.

Distribution. - Endemic to Sardinia.

Helichrysum valentinum Rouy in T. Durand \& B.D. Jackson, Index Kew., Suppl. 1: 199. 1902 - Neotype (designated by Galbany-Casals \& al., 2006c: 499): Denia, Le Mongo çà et là sur les parois des hauts rochers, 1-VI-1889, Rouy s.n. (LY 0006931 photo!).

Habitat. - Limestone rock crevices, in mountain areas and coastal cliffs. Altitudinal range: 30-1300 m. Distribution. - E of the Iberian Peninsula in Alicante province.

\section{- ACKNOWLEDGMENTS}

We are grateful to the curators of all herbaria and to J.J. Aldasoro, S. Arrabal, E. Blanco, J.A. Devesa, N. Garcia-Jacas, A. Hilpold, S. Massó, S. Lanfranco, J.X. Soler, A. Susanna, and J. Xiberras for providing plant material or field assistance for this work. J.X. Soler and J. Xiberras have also provided helpful information and stimulating discussion on $H$. valentinum and $H$. melitense, respectively. Three anonymous reviewers and the editors made valuable suggestions that contributed to improve this work. Financial support from the Spanish Ministerio de Ciencia e Inovación CGL2007-60781/BOS, CGL2009-13322-C03-03/BOS, CGL2010-18631/BOS) and the Catalan government ('Ajuts a grups consolidats'2009/SGR/00439 and 2014/SGR/514) is also acknowledged.

\section{- LITERATURE CITED}

Aghababyan, M., Greuter, W., Mazzola, P. \& Raimondo, F.M. 2007. Typification of Sicilian Helichrysum (Compositae) revisited. Taxon 56: 1285-1288. http://dx.doi.org/10.2307/25065922

Arrigoni, P.A., Camarda, I., Corrias, B., Diana-Corrias, S., Raffaelli, M. \& Valsecchi, F. 1980. Le piante endemiche della Sardegna. Boll. Soc. Sarda. Sci. Nat. 19: 217-254.

Arroyo, J., Aparicio, A., Albaladejo, R.G., Muñoz, J. \& Braza, R. 2008. Genetic structure and population differentiation of the Mediterranean pioneer spiny broom Calicotome villosa across the Strait of Gibraltar. Biol. J. Linn. Soc. 93: 39-51. http://dx.doi.org/10.1111/j.10958312.2007.00916.x

Baccheta, G., Brullo, S. \& Mossa, L. 2003. Note tassonomiche sul genere Helichrysum Miller (Asteraceae) in Sardegna. Inf. Bot. Ital. 35: 217-225. 
Baldwin, B.G. \& Markos, S. 1998. Phylogenetic utility of the external transcribed spacer (ETS) of 18S26S rDNA: congruence of ETS and ITS trees of Calycadenia (Compositae). Molec. Phylogenet. Evol. 10: 449-463. http://dx.doi.org/10.1006/mpev.1998.0545

Barres, L., Vilatersana, R., Molero, J., Susanna, A. \& Galbany-Casals, M. 2011. Molecular phylogeny of Euphorbia subg. Esula sect. Aphyllis (Euphorbiaceae) inferred from nrDNA and cpDNA markers with biogeographic insights. Taxon 60: 705-720.

Beerli, P., Hotz, H. \& Uzzell, T. 1996. Geologically dated sea barriers calibrate a protein clock for Aegean water frogs. Evolution 50: 1676-1687. http://dx.doi.org/10.2307/2410903

Blanco-Pastor, J.L., Vargas, P \& Pfeil, B.E. 2012. Coalescent simulations reveal hybridization and incomplete lineage sorting in Mediterranean Linaria. PLoS ONE 7: e39089. http://dx.doi.org/10.1371/journal.pone.0039089

Bolòs, O. \& Vigo, J. 1996. Flora dels Països Catalans, vol. 3. Barcelona: Ed. Barcino.

Brullo, S., Lanfranco, E., Pavone, P. \& Ronsisvalle, G. 1988. Taxonomical notes on the endemic flora of Malta. Giorn. Bot. Ital. 122: 9.

Cambessèdes, J. 1827. Enumeratio plantarum, quas in insulis Balearibus collegit J. Cambessèdes, earumque circa Mare Mediterraneum distributio geographica. Mém. Mus. Hist. Nat. 14: 173335.

Clapham, A.R. 1976. Helichrysum Mill. Pp. 128-131 in: Tutin, T.G., Heywood, V.H., Burges, N.A., Moore, D.M., Valentine, D.H., Walters, S.M. \& Webb, D.A. (eds.), Flora Europaea, vol. 4. Cambridge: Cambridge University Press.

Clement, M., Posada D. \& Crandall K.A. 2000. TCS: a computer program to estimate gene genealogies. Molec. Ecol. 9: 1657-1659. http://dx.doi.org/10.1046/j.1365-294x.2000.01020.x

Comes, H.P. \& Abbott, R.J. 2001. Molecular phylogeography, reticulation, and lineage sorting in Mediterranean Senecio sect. Senecio (Asteraceae). Evolution 55: 1943-1962. http://dx.doi.org/10.1111/j.0014-3820.2001.tb01312.x

Conesa, M.A., Mus, M. \& Rosselló, J.A. 2010. Who threatens who? Natural hybridization between Lotus dorycnium and the island endemic Lotus fulgurans (Fabaceae). Biol. J. Linn. Soc. 101: 112. http://dx.doi.org/10.1111/j.1095-8312.2010.01456.x

Conesa, M.A. Mus, M. \& Roselló, J.A. 2012. Leaf shape variation and taxonomic boundaries in two sympatric rupicolous species of Helichrysum (Asteraceae: Gnaphalieae), assessed by linear measurements and geometric morphometry. Biol. J. Linn. Soc. 106: 498-513. http://dx.doi.org/10.1111/j.1095-8312.2012.01889.x

Corander, J., Sirén, J. \& Arjas, E. 2008. Bayesian spatial modelling of genetic population structure. Comput. Stat. 23: 111-129. http://dx.doi.org/10.1007/s00180-007-0072-x

Corriveau, J.L. \& Coleman, A.W. 1988. Rapid screening method to detect potential biparental inheritance of plastid DNA and results for over 200 angiosperm species. Am. J. Bot. 70: 14431458. http://dx.doi.org/10.2307/2444695

Cowie, R.H. \& Holland, B.S. 2006. Dispersal is fundamental to biogeography and the evolution of biodiversity on oceanic islands. J. Biogeogr. 33: 193-198. http://dx.doi.org/10.1111/j.13652699.2005.01383.x

Crespo, M.B. \& Mateo, G. 2010. Novedades taxonómicas y nomenclaturales para la Flora Valenciana, II. Fl. Montib. 45: 89-102.

Cullings, K.W. 1992. Design and testing of a plant-specific PCR primer from ecological and evolutionary studies. Molec. Ecol. 1: 233-240. http://dx.doi.org/10.1111/j.1365-294X.1992.tb00182.x

Dayrat, B. 2005. Towards integrative taxonomy. Biol. J. Linn. Soc. 85: 407-415. http://dx.doi.org/10.1111/j.1095-8312.2005.00503.x

Doyle, J.J. \& Dickson, E.E. 1987. Preservation of plant samples for DNA restriction endonuclease analysis. Taxon 36: 715-722. http://dx.doi.org/10.2307/1221122

Duggen, S., Hoernle, K., van den Bogaard, P., Rüpke, L. \& Morgan, J.P. 2003. Deep roots of the Messinian salinity crisis. Nature 402: 602-606. http://dx.doi.org/10.1038/nature01553

Excoffier, L., Laval, G. \& Schneider, S. 2005. Arlequin (version 3.0): An integrated software package for population genetics data analysis. Evol. Bioinf. Online 1: 47-50.

Excoffier, L., Smouse, P.E. \& Quattro J.M. 1992. Analysis of molecular variance inferred from metric distances among DNA haplotypes: Application to human mitochondrial DNA restriction data. Genetics 131: 479-491.

Fehrer, J., Gemeinholzer, B., Chrtek, J. \& Bräutigam, S. 2007. Incongruent plastid and nuclear DNA phylogenies reveal ancient intergeneric hybridization in Pilosella hawkweeds (Hieracium, Chichorieae, Asteraceae). Molec. Phylogenet. Evol. 42: 374-361. http://dx.doi.org/10.1016/j.ympev.2006.07.004 
1120

1121

1122

1123

1124

1125

1126

1127

1128

1129

1130

1131

1132

1133

1134

1135

1136

1137

1138

1139

1140

1141

1142

1143

1144

1145

1146

1147

1148

1149

1150

1151

1152

1153

1154

1155

1156

1157

1158

1159

1160

1161

1162

1163

1164

1165

1166

1167

1168

1169

1170

1171

1172

1173

1174

1175

1176

1177

1178

Felsenstein, J. 1985. Confidence limits on phylogenies: An approach using the bootstrap. Evolution 39: 783-791. http://dx.doi.org/10.2307/2408678

Fennane, M. \& Ibn Tattou, M. 1998. Catalogue des plantes vasculaires rares, menacées ou -endémiques du Maroc. Bocconea 8: 1-242.

Fernández-Mazuecos, M. \& Vargas, P. 2011. Historical isolation versus recent long-distance connections between Europe and Africa in bifid toadflaxes (Linaria sect. Versicolores). PLoS ONE 6: e22234. http://dx.doi.org/10.1371/journal.pone.0022234

Fiori, A. 1927. Nuova Flora Analitica d'Italia 2. Firenze: Ed. M. Ricci.

Fiz, O., Valcárcel, V. \& Vargas, P. 2002. Phylogenetic position of Mediterranean Asteraceae and character evolution of daisies (Bellis, Asteraceae) inferred from nrDNA ITS sequences. Molec. Phylogenet. Evol. 25: 157-171. http://dx.doi.org/10.1016/S1055-7903(02)00228-2

Galbany-Casals, M., Andrés-Sánchez, S., Garcia-Jacas, N., Susanna, A., Rico, E. \& MartínezOrtega, M.M. 2010. How many of Cassini anagrams should there be? Molecular systematics and phylogenetic relationships in the Filago group (Asteraceae, Gnaphalieae), with special focus on the genus Filago. Taxon 59: 1671-1689.

Galbany-Casals, M., Blanco-Moreno, J.M., Garcia-Jacas, N., Breitwieser, I. \& Smissen, R.D. 2011. Genetic and morphological variation in the Mediterranean Helichrysum italicum (Asteraceae; Gnaphalieae): do disjunct populations of subsp. microphyllum have a common origin? Plant Biol. 13: 678-687. http://dx.doi.org/10.1111/j.1438-8677.2010.00411.x

Galbany-Casals, M., Carnicero-Campmany, P., Blanco-Moreno, J.M. \& Smissen, R.D. 2012. Morphological and genetic evidence of contemporary intersectional hybridization in Mediterranean Helichrysum (Asteraceae, Gnaphalieae). Plant Biol. 14: 789-800. http://dx.doi.org/10.1111/j.1438-8677.2012.00568.x

Galbany-Casals, M., Garcia-Jacas, N., Sáez, L., Benedí, C. \& Susanna, A. 2009. Phylogeny, biogeography, and character evolution in Mediterranean, Asiatic and Macaronesian Helichrysum (Asteraceae, Gnaphalieae) inferred from nuclear phylogenetic analyses. Int. J. Plant Sci. 170: 365-380. http://dx.doi.org/10.1086/596332

Galbany-Casals, M., Sáez, L. \& Benedí, C. 2006a. A taxonomic revision of Helichrysum Mill. sect. Stoechadina (DC.) Gren. \& Godr. (Asteraceae, Gnaphalieae). Canad. J. Bot. 84: 1203-1232. http://dx.doi.org/10.1139/b06-082

Galbany-Casals, M., Sáez, L. \& Benedí, C. 2006b. Conspectus of Helichrysum Mill. sect. Stoechadina (DC.) Gren \& Godr. (Asteraceae, Gnaphalieae). Orsis 21: 58-81.

Galbany-Casals, M., Sáez, L., Benedí, C. \& Jarvis, C.E. 2006c. Typification of names in Gnaphalium L. and Helichrysum Mill. (Asteraceae), and some taxonomic notes. Taxon 55: 489-501. https://doi.org/10.2307/25065597

Galbany-Casals, M., Unwin, M., Garcia-Jacas, N., Smissen R.D., Susanna, A. \& Bayer R.J. 2014. Phylogenetic relationships in Helichrysum (Compositae: Gnaphalieae) and related genera: Incongruence implications for generic delimitation. Taxon 63: 608-624. http://dx.doi.org/10.12705/633.8

Giardina, G., Raimondo, F.M. \& Spadaro, V. 2007. A catalogue of the plants growing in Sicily. Bocconea 20: 5-584.

Gil, L. 1994. Biología reproductiva de la flora litoral de las Islas Baleares. I. Dunas y roquedos marítimos. Unpublished PhD Thesis, University of the Balearic Islands, Palma de Mallorca.

Greuter, W. (2006+): Compositae (pro parte majore). In: Greuter, W. \& Raab-Straube, E. von (eds.): Compositae. Euro+Med Plantbase - the information resource for Euro-Mediterranean plant diversity. http://ww2.bgbm.org/EuroPlusMed/ (accessed on Aug 2015)

Grimm, G.W. \& Denk, T. 2008. ITS evolution in Platanus (Platanaceae): homoeologues, pseudogenes and ancient hybridization. Ann. Bot. 101: 403-419. http://dx.doi.org/10.1093/aob/mcm305

Gussone, G. 1844. Florae siculae synopsis exhibens plantas vasculares in Sicilia insulisque adjacentibus huc usque detectas secundum systema linneanum depositas 2. Napoli.

Guzmán, B. \& Vargas, P. 2009. Long distance colonisation by the Mediterranean Cistus ladanifer (Cistaceae) despite the absence of special dispersal mechanisms. J. Biogeogr. 36: 954-968. http://dx.doi.org/10.1111/j.1365-2699.2008.02040.x

Hilpold, A., Schönswetter, P., Susanna, A., Garcia-Jacas, N. \& Vilatersana, R. 2011. Evolution of the central Mediterranean Centaurea cineraria group (Asteraceae): evidence for relatively recent, allopatric diversification following transoceanic seed dispersal. Taxon 60: 528-538.

Hsü, K.J., Montardet, P., Bernoulli, D., Cita, M.B., Erickson, A., Garrison, R.E., Kidd, R., Mèlierés, F., Müller, C. \& Wright, R. 1977. History of the Mediterranean salinity crisis. Nature 267: 399403. http://dx.doi.org/10.1038/267399a0 
Huson, D.H. \& Bryant, D. 2006. Application of phylogenetic networks in evolutionary studies. Molec. Biol. Evol. 23: 254-267. http://dx.doi.org/10.1093/molbev/msj030

Jackson, H.D., Steane, D.A., Potts, B.M. \& Vaillancourt, R.E. 1999. Chloroplast DNA evidence for reticulate evolution in Eucalyptus (Myrtaceae). Molec. Ecol. 8: 739-751. http://dx.doi.org/10.1046/j.1365-294X.1999.00614.X

Jolliffe, I.T. 2002. Principal Component Analysis. 2nd ed. New York: Springer Series in Statistics.

Junikka, L., Uotila, P. \& Lahti, T. 2006. A phytogeographical comparison of the major Mediterranean islands on the basis of Atlas Florae Europaeae. Willdenowia 36: 379-388. http://dx.doi.org/10.3372/wi.36.36134

Koch, M.A., Karl, R., \& German, D.A. 2016. Underexplored biodiversity of Eastern Mediterranean biota: systematics and evolutionary history of the genus Aubrieta (Brassicaceae). Ann. Bot. 119: 39-57. http://dx.doi.org/10.1093/aob/mcw204

Lavergne, S., Hampe, A. \& Arroyo, J. 2013. In and out of Africa: How did the Strait of Gibraltar affect plant species migration and local diversification? J. Biogeogr. 40: 24-36. http://dx.doi.org/10.1111/j.1365-2699.2012.02769.x

Lee, J.H., Lee, D.H. \& Choi, B.H., 2013. Phylogeography and genetic diversity of East Asian Neolitsea sericea (Lauraceae) based on variations in chloroplast DNA sequences. J. Plant. Res. 126: 193202. http://dx.doi.org/10.1007/s10265-012-0519-1

Linder, C.R., Goertzen, L.R., Heuvel, B.V., Francisco-Ortega, J. \& Jansen, R.K. 2000. The complete external transcribed spacer of 18S-26S rDNA: Amplification and phylogenetic utility at low taxonomic levels in Asteraceae and closely allied families. Molec. Phylogenet. Evol. 14: 285303. http://dx.doi.org/10.1006/mpev.1999.0706

Lo Presti, R.M. \& Oberprieler, C. 2011. The central Mediterranean as a phytodiversity hotchpotch: phylogeographical patterns of the Anthemis secundiramea group (Compositae, Anthemideae) across the Sicilian Channel. J. Biogeogr. 38: 1109-1124. http://dx.doi.org/10.1111/j.13652699.2010.02464.x

Lojacono Pojero, M. 1889-1908. Flora Sicula, vol. 5. Palermo: Tip. Vzì.

Lumaret, R., Mir, C., Michaud, H. \& Raynal, V. 2002. Phylogeographical variation of chloroplast DNA in holm oak (Quercus ilex L.). Molec. Ecol. 11: 2327-2336. http://dx.doi.org/10.1046/j.1365-294X.2002.01611.x

Manni, F., Guerard, E. \& Heyer, E. 2004. Geographic patterns of (genetic, morphologic, linguistic) variation: how barriers can be detected by using Monmonier's algorithm. Hum. Biol. 76: 173190. http://dx.doi.org/10.1353/hub.2004.0034

Markos, S. \& Baldwin, B.G. 2001. Higher-level relationships and major lineages of Lessingia (Compositae, Astereae) based on nuclear rDNA internal and external transcribed spacers (ITS and ETS) sequences. Syst. Bot. 26: 168-183.

Mateo, G. 2005. De Flora Valentina, VIII. Fl. Montib. 29: 92-95.

Mateo, G. \& Crespo, M. 2008. Novedades taxonómicas y nomenclaturales para la Flora Valenciana. $F l$. Montib. 40: 60-70.

Mateo, G., Crespo, M.B. \& Laguna, E. 2013. Flora Valentina. Flora Vascular de la Comunidad Valenciana, vol. 2. Valencia: Fundación de la Comunidad Valenciana para el Medio Ambiente.

Moris, G.G. 1840-1843. Flora Sardoa, vol. 2. Taurini: Regio Typographeo.

Müller, K. 2006. Incorporating information from length-mutational events into phylogenetic analysis. Molec. Phylogenet. Evol. 38: 667-676. http://dx.doi.org/10.1016/j.ympev.2005.07.011

Myers, N., Mittermeier, R.A., Mittermeier, C.G., Fonseca, G.A.B. \& Kent, J. 2000. Biodiversity hotspots for conservation priorities. Nature 403: 853-858. http://dx.doi.org/10.1038/35002501

Nei, M. 1972. Genetic distances between populations. Am. Nat. 106: 283-291. https://doi.org/10.1086/282771

Nie, Z. L., Funk, V. A., Meng, Y., Deng, T., Sun, H. \& Wen, J. 2016. Recent assembly of the global herbaceous flora: evidence from the paper daisies (Asteraceae: Gnaphalieae). New Phytol. 209: 1795-1806. http://dx.doi.org/10.1111/nph.13740

Nieto-Feliner, G. 2014. Patterns and processes in plant phylogeography in the Mediterranean Basin. A review. Perspect. Plant Ecol. Evol. Syst. 16: 265-278. http://dx.doi.org/10.1016/j.ppees.2014.07.002

Nyman, C.F. 1879. Conspectus florae Europaeae seu. Örebro; Officinae Bohlinianae.

Ortiz, M.Á., Tremetsberger, K., Talavera, S., Stuessy, T. \& García-Castro, L. 2007. Population structure of Hypochaeris salzmanniana DC. (Asteraceae), an endemic species to the Atlantic coast on both sides of the Strait of Gibraltar, in relation to Quaternary sea level changes. Molec. Ecol. 16: 541-552. http://dx.doi.org/10.1111/j.1365-294X.2006.03157.x 
Peakall, R. \& Smouse, P.E. 2012. GenAlEx 6.5: genetic analysis in Excel. Population genetic software for teaching and research - an update. Bioinformatics 28: 2537-2539. http://dx.doi.org/10.1093/bioinformatics/bts460

Petit, R.J., Aguinagalde, I., de Beaulieu, J.-L., Bittkau, Ch., Brewer, S., Cheddadi, R., Ennos, R., Fineschi, S., Grivet, D., Lascoux, M., Mohanty, A., Müller-Starck, G., Demesure-Musch, B., Palmé, A., Martín J.P., Rendell, S., Vendramin, G.G. 2003. Glacial refugia: Hotspots but not melting pots of genetic diversity. Science 300: 1563-1565. http://dx.doi.org/10.1126/science.1083264

Pignatti, S. 1980. Note critiche sulla Flora d'Italia. VI. Ultimi appunti miscellanei. Giorn. Bot. Ital. 113: 359-368. https://doi.org/10.1080/11263507909426411

Pignatti, S. 1982. Flora d'Italia, vol. 3. Bologna: Edagricole.

Posada, D. 2008. jModelTest: Phylogenetic model averaging. Molec. Biol. Evol. 25: 1253-1256. http://dx.doi.org/10.1093/molbev/msn083

Presl, K.B. 1826. Flora Sicula, exhibens plantas vasculosas in Sicilia aut sponte crescentes aut frequentissime cultas, secundum systema naturale digestas, vol. 1. Pragae: Sumptibus A. Borrosch.

Rambaut, A. 2009. FigTree v.3.1. http://tree.bio.ed.ac.uk/software/figtree/ (accessed on 2014-6).

Rambaut, A., Suchard, M.A., Xie, D. \& Drummond, A.J. 2013. Tracer v1.6. http://beast.bio.ed.ac.uk/software/tracer/ (accessed on 2014-6).

Rodríguez-Sánchez, F., Pérez-Barrales, R., Ojeda, F., Vargas, P. \& Arroyo, J. 2008. The Strait of Gibraltar as a melting pot for plant biodiversity. Quat. Sci. Rev. 27: 2100-2117. http://dx.doi.org/10.1016/j.quascirev.2008.08.006

Ronikier, M., Schneeweiss, G.M., \& Schönswetter, P. 2012. The extreme disjunction between Beringia and Europe in Ranunculus glacialis s.l. (Ranunculaceae) does not coincide with the deepest genetic split - a story of the importance of temperate mountain ranges in arctic-alpine phylogeography. Molec. Ecol. 21: 5561-5578. http://dx.doi.org/10.1111/mec.12030

Ronquist, F. \& Huelsenbeck, J.P. 2003. MRBAYES 3: Bayesian phylogenetic inference under mixed models. Bioinformatics 19: 1572-1574. http://dx.doi.org/10.1093/bioinformatics/btg180

Rosenbaum, G., Lister, G.S. \& Duboz, C. 2002. Reconstruction of the tectonic evolution of the western Mediterranean since the Oligocene. J. Virtual Explor. 8: 107-130. http://dx.doi.org/10.3809/jvirtex.2002.00053

Rouy, G. 1888. Excursions botaniques en Espagne. Bull. Soc. Bot. France 35: 115-124. https://doi.org/10.1080/00378941.1888.10830325

Rubio de Casas, R., Besnard, G., Schönswetter, P., Balaguer, L. \& Vargas, P. 2006. Extensive gene flow blurs phylogeographic but not phylogenetic signal in Olea europaea L. Theor. Appl. Genet. 113: 575-583. http://dx.doi.org/10.1007/s00122-006-0306-2

Schlick-Steiner, B.C., Steiner, F.M., Seifert, B., Stauffer, C., Christian, E., \& Crozier, R.H. 2010. Integrative taxonomy: a multisource approach to exploring biodiversity. Annu. Rev. Entomol. 55: 421-438. http://dx.doi.org/10.1146/annurev-ento-112408-085432

Scialabba, A., Agrimonti, C., Abbate, G.M. \& Marmiroli, N. 2008. Assessment of genetic variation in Sicilian Helichrysum (Asteraceae) and implications to germplasm conservation. Plant Biosys. 142: 287-297. http://dx.doi.org/10.1080/11263500802150530

Sciberras, J. \& Sciberras, A. 2009. Notes on the distribution of Helichrysum melitense, Hyoseris frutescens and Matthiola incana subsp. melitensis in the Maltese Islands. The Central Mediterranean Naturalist 5: 28-34.

Shaw, J., Lickey, E.B., Schilling, E.E. \& Small, R.L. 2007. Comparison of whole chloroplast genome sequences to choose noncoding regions for phylogenetic studies in angiosperms: The tortoise and the hare III. Am. J. Bot. 94: 275-288. http://dx.doi.org/10.3732/ajb.94.3.275

Smissen, R.D., Breitwiser, I. \& Wardm J.M. 2004. Phylogenetic implications of trans-specific chloroplast DNA sequence polymorphism in New Zealand Gnaphalieae (Asteraceae). Plant Syst. Evol. 249: 37-53. http://dx.doi.org/10.1007/s00606-004-0209-0

Smissen, R. D., Breitwieser, I. \& Ward, J. M. 2007. Genetic characterization of hybridization between the New Zealand everlastings Helichrysum lanceolatum and Anaphalioides bellidioides (Asteraceae: Gnaphalieae). Bot. J. Linn. Soc. 154: 89-98. http://dx.doi.org/10.1111/j.10958339.2007.00632.x

Smissen, R. D., Galbany-Casals, M. \& Breitwieser, I. 2011. Ancient allopolyploidy in the everlasting daisies (Asteraceae: Gnaphalieae): complex relationships among extant clades. Taxon 60: 649662.

Stephens, M., Smith, N.J. \& Donnelly, P. 2001. A new statistical method for haplotype reconstruction from population data. Am. J. Hum. Genet. 68: 978-989. http://dx.doi.org/10.1086/319501 
Stöck, M., Sicilia, A., Belfiore, N.M., Buckley, D., Lo Brutto, S., Lo Valvo, M. \& Arculeo, M. 2008. Post Messinian evolutionary relationships across the Sicilian channel: mitochondrial and nuclear markers link a new green toad from Sicily to African relatives. B.M.C. Evol. Biol. 8: 56. http://dx.doi.org/10.1186/1471-2148-8-56

Swofford, D.L. 2002. PAUP*: Phylogenetic analysis using parsimony (*and other methods), version 4.0 Beta. Sunderland: Sinauer.

Tamura, K., Stecher, G., Peterson, D., Filipski, A. \& Kumar, S. 2013. MEGA6: Molecular evolutionary genetics analysis version 6.0. Molec. Biol. Evol. 30: 2725-2729. http://dx.doi.org/10.1093/molbev/mst197

Tel-Zur, N., Abbo, S., Myslabodski, D. \& Mizrahi, Y. 1999. Modified CTAB procedure for DNA isolation from epiphytic cacti of genera Hylocereus and Selenicereus (Cactaceae). Plant Molec. Biol. Rep. 17: 249-254. http://dx.doi.org/10.1023/A:1007656315275

Templeton, A.R., Crandall, K.A. \& Sing, C.F. 1992. A cladistic analysis of phenotypic associations with haplotypes inferred from restriction endonuclease mapping and DNA sequence data. III. Cladogram estimation. Genetics 123: 585-595.

Terrab, A., Schönswetter, P., Talavera, S., Vela, E. \& Stuessy, T.F. 2008. Range-wide phylogeography of Juniperus thurifera L., a presumptive keystone species of western Mediterranean vegetation during cold stages of the Pleistocene. Molec. Phylogenet. Evol. 48: 94-102. http://dx.doi.org/10.1016/j.ympev.2008.03.018

Thompson, J.D. 2005. Plant evolution in the Mediterranean. Oxford: Oxford University Press. https://doi.org/10.1093/acprof:oso/9780198515340.001.0001

Troia, A., Raimondo, F.M. \& Geraci, A. 2012. Does genetic population structure of Ambrosina bassii L. (Araceae, Ambrosineae) attest a post-Messinian land-bridge between Sicily and Africa? Flora 207: 646-653. http://dx.doi.org/10.1016/j.flora.2012.06.017

Valdés, B., Talavera, S. \& Fernández-Galiano, E. (eds.). 1987. Flora Vascular de Andalucía Occidental, vol. 3. Barcelona: Ketres editora.

Wallmann, P.C., Mahood, G.A. \& Pollard, D.D. 1988. Mechanical models for correlation of ringfracture eruptions at Pantelleria, Strait of Sicily, with glacial sea-level drawdown. Bull. Volc. 50: 327-339. https://doi.org/10.1007/bf01073589

Wendel, J.F. \& Doyle, J.J. 1998. Phylogenetic incongruence: Window into genome history and molecular evolution. Pp. 256-296 in: Soltis, D.E., Soltis, P.S. \& Doyle, J.J. (eds.), Molecular systematics of plants II. DNA sequencing. Boston: Kliwer Academic Publishers. http://dx.doi.org/10.1007/978-1-4615-5419-6_10

Woodward, J.C. 2009. The physical geography of the Mediterranean. Oxford: Oxford University Press.

Xiberras, J. 2013. Population studies on Helichrysum melitense. Malta: Department of Biology, University of Malta.

Yeates, D.K., Seago, A., Nelson, L., Cameron, S.L., Joseph, L. \& Trueman, J.W. 2011. Integrative taxonomy, or iterative taxonomy? Syst. Entomol. 36: 209-217. http://dx.doi.org/10.1111/j.13653113.2010.00558.x

Yokoyama, Y., Lambeck, K., De Deckker, P., Johnston, P. \& Fifield, L.K. 2000. Timing of the Last Glacial Maximum from observed sea-level minima. Nature 406: 713-716. http://dx.doi.org/10.1038/35021035

Zozomová-Lihová, J., Marhold, K. \& Španiel, S. 2014. Taxonomy and evolutionary history of Alyssum montanum (Brassicaceae) and related taxa in southwestern Europe and Morocco: Diversification driven by polyploidy, geographic and ecological isolation. Taxon 63: 562-591. http://dx.doi.org/10.12705/633.18 
Table 1. Morphological variables used in morphometric analyses. Type of characters are: qualitative $(\mathrm{QL})$, quantitative $(\mathrm{QN})$ and semiquantitative $(\mathrm{SQN})$.

\begin{tabular}{lc}
\hline \multicolumn{1}{c}{ Morphological characters } & $\begin{array}{c}\text { Type of } \\
\text { character }\end{array}$ \\
\hline Vegetative characters & QL \\
1. Presence (1) / absence (0) of succulent leaves ${ }^{1}$ & QN \\
2. Basal and median cauline leaf length (mm) & QN \\
3. Basal and median cauline leaf width (mm) & QN \\
4. Basal and median cauline leaf length / width & SQN \\
5. Basal and median leaf margin (flat or revolute) $(0-4)^{2}$ & SQN \\
6. Eglandular indumentum of adaxial leaf side $(0-4)^{3}$ & SQN
\end{tabular}

Floral characters

8. Synflorescence length $(\mathrm{mm})$

QN

9. Synflorescence width $(\mathrm{mm})$

QN

10. Synflorescence length / synflorescence width $\quad$ QN

11. Number of capitula per synflorescence QN

12. Synflorescence density ${ }^{4,5}$ QN

13. Capitulum length $(\mathrm{mm}) \quad$ QN

14. Capitulum width $(\mathrm{mm}) \quad$ QN

15. Capitulum length / capitulum width QN

16. Number of pistillate florets per capitulum QN

17. Number of hermaphroditic florets per capitulum $\quad$ QN

18. Total number of florets per capitulum $\quad$ QN

19. Number of pistillate florets per capitulum / total number of florets per capitulum QN

20. Outermost involucral bract length $(\mathrm{mm}) \quad$ QN

21. Outermost involucral bract width $(\mathrm{mm}) \quad$ QN

22. Outermost involucral bract length / outermost involucral bract width QN

23. Outermost involucral bract texture $(0-1)^{6} \quad$ SQN

24. Eglandular indumentum of outermost involucral bract $(0-4)^{3} \quad$ SQN

25. Innermost involucral bract length $(\mathrm{mm}) \quad$ QN

26. Innermost involucral bract width $(\mathrm{mm}) \quad$ QN

27. Innermost involucral bract length / innermost involucral bract width QN

28. Eglandular indumentum of innermost involucral bract $(0-4)^{3,7} \quad$ SQN

29. Glandular indumentum of innermost involucral bract $(0-4)^{3} \quad$ SQN

30. Average of innermost involucral bract length / outermost involucral bract length QN

31. Number of involucral bracts per capitulum $\quad$ QN

${ }^{1}$ Only used in PCA3

${ }^{2} 0$ : all leaves flat; 1: most leaves flat, some revolute; 2: flat and revolute leaves in the same proportion; 3: most leaves revolute, some flat; 4: all leaves revolute.

${ }^{3} 0$ : $0-5 \%$ coverage; $1: 6-25 \%$ coverage; $2: 26-50 \%$ coverage; $3: 51-75 \%$ coverage; $4: 76-100 \%$ coverage.

${ }^{4}$ Number of capitula per synflorescence / (synflorescence lenght $\times$ synflorescence width).

${ }^{5}$ Only used in PCA3 and CDA because data were not available for all specimens.

${ }^{6} 0$ : bract totally papery; 0.5 : bract herbaceous in its basal half and papery in its distal half; 1 : bract totally herbaceous

${ }^{7}$ Only two states in PCA3 and was coded as qualitative in that analysis. 
Table 2. Analyses of molecular variance (AMOVA) based on the rpl32-trnL spacer and ETS sequence data for the Helichrysum pendulum complex

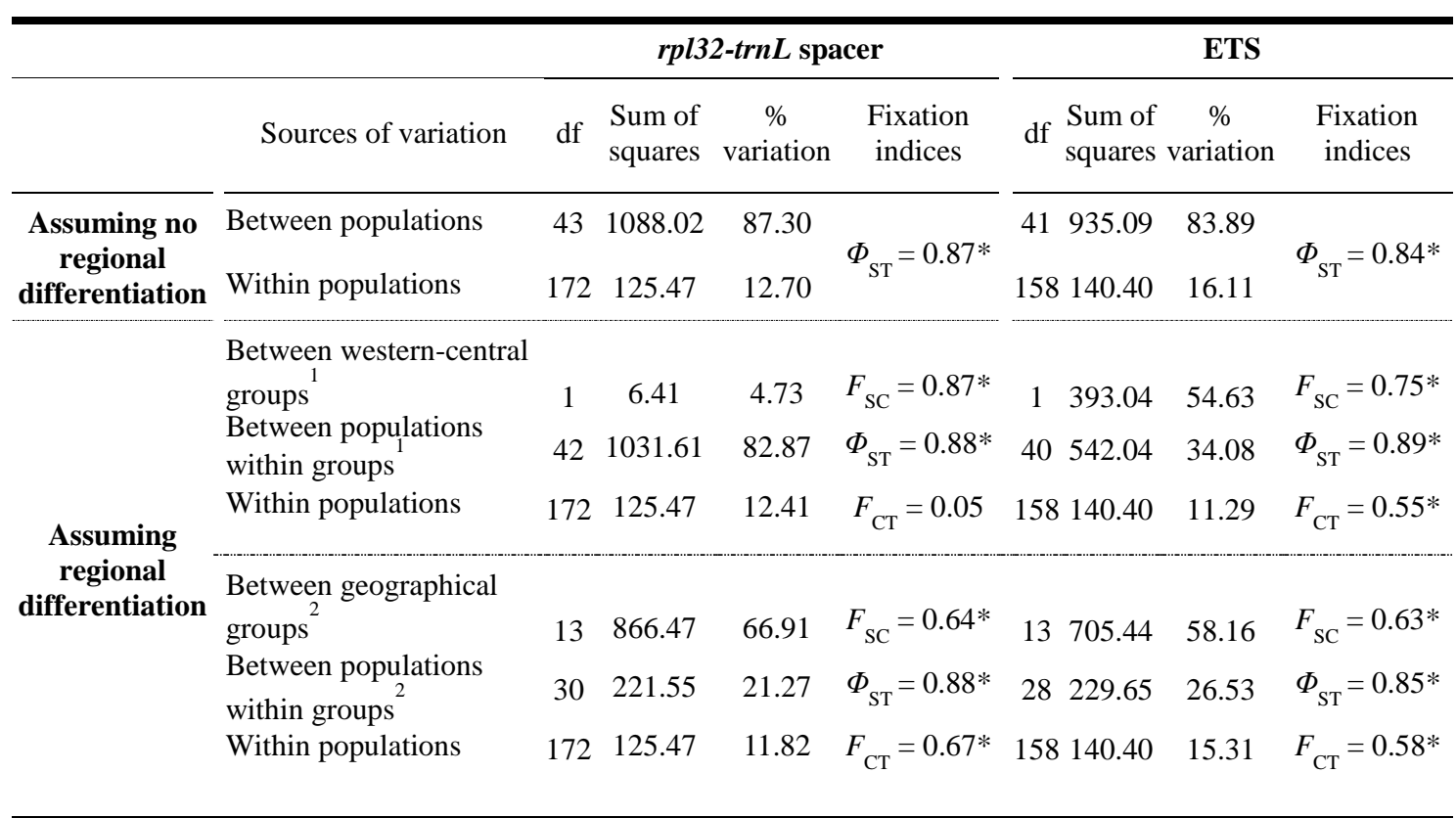

${ }^{1}$ Western-central groups: western Mediterranean group includes Majorca, Ibiza, Imperialet, Vedranell, Es Vedrà, 1407 Alicante, Gibraltar, Morocco and Algeria; central Mediterranean group includes Sardinia, Sicily, Marettimo, Pantelleria and Malta.

14092 Geographical groups: Majorca, Imperialet, Ibiza, Vedranell, Es Vedrà, Alicante, Gibraltar, Morocco, Algeria, 1410 Sardinia, Sicily, Marettimo, Pantelleria and Malta.

$1411 * p<0.001$ (significant after 1023 permutations) 
Previous taxonomic treatment / Final taxonomic treatment

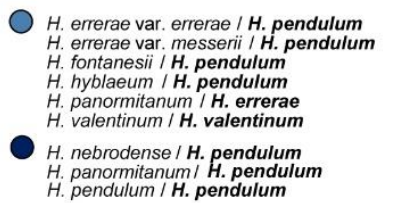

A

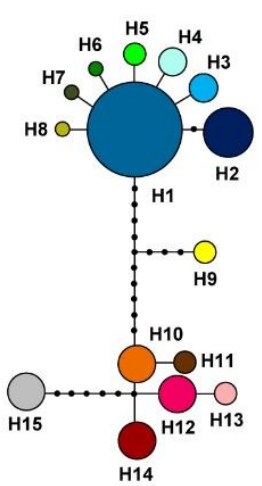

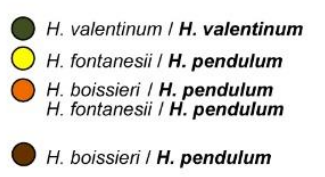

H. saxatile / H. saxatile

H. saxatile / H. saxatile

H. saxatile / H. saxatile

H. melitense / H. melitense

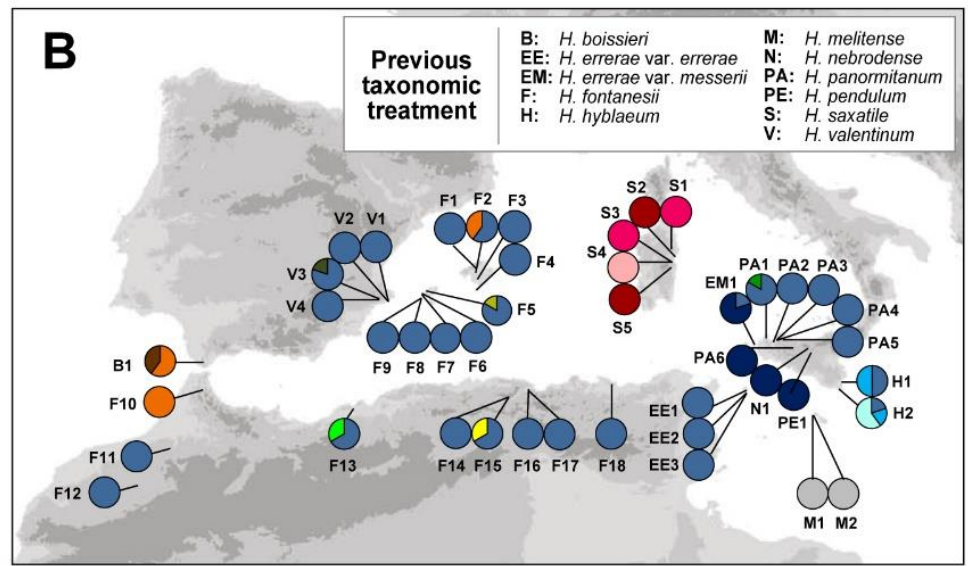

C

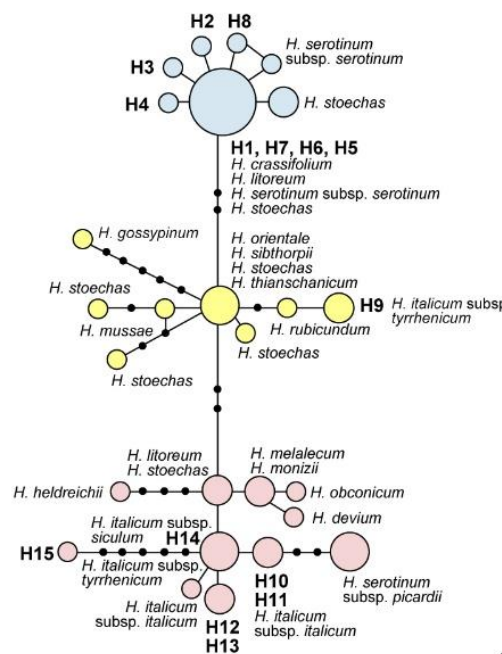

D
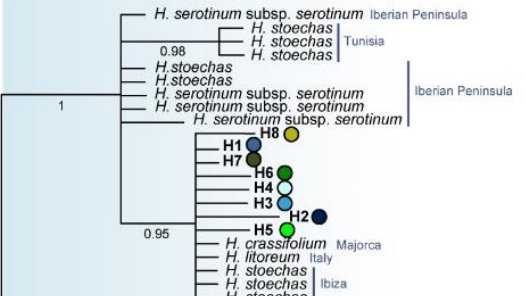

EH. stoechas 1 .
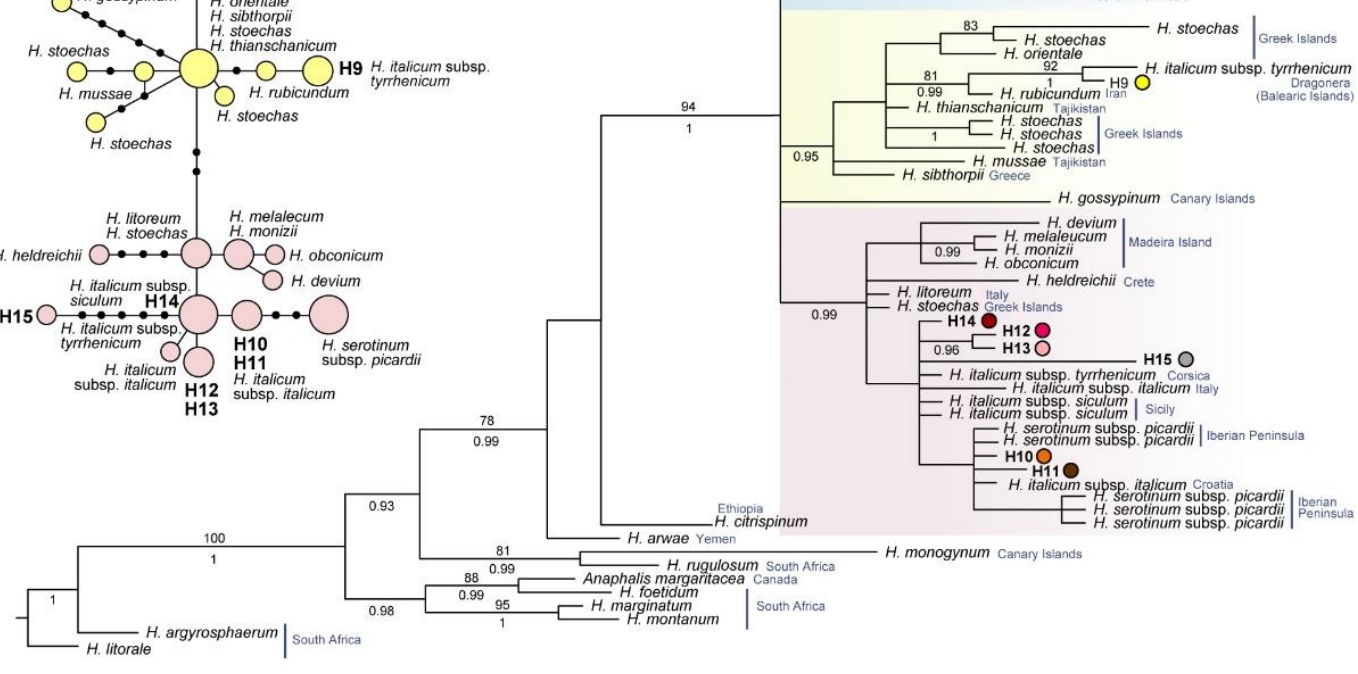

Fig. 1. A, Parsimony network relationships of the 15 different haplotypes found in the 216 individuals of the Helichrysum pendulum complex. The size of circles is proportional to the frequency of each haplotype in the total sample. Small black circles represent intermediate haplotypes that were not detected. Lines between circles represent one mutational step. B, Geographical distribution of the 15 different haplotypes obtained. For population abbreviation codes and additional information see Electr. Suppl.: Table S1. C, Parsimony network relationships of the 15 haplotypes detected in the $H$. pendulum complex and the other species of the Mediterranean-Macaronesian-Asiatic clade. D, Phylogram obtained from Bayesian analysis of the 15 haplotypes detected and the rest of the species included in the study (dataset 3, see text for details). Bootstrap values from the maximum parsimony analysis are shown above and Bayesian posterior probabilities are shown below branches. 


\section{Previous taxonomic treatment / Final taxonomic treatment}

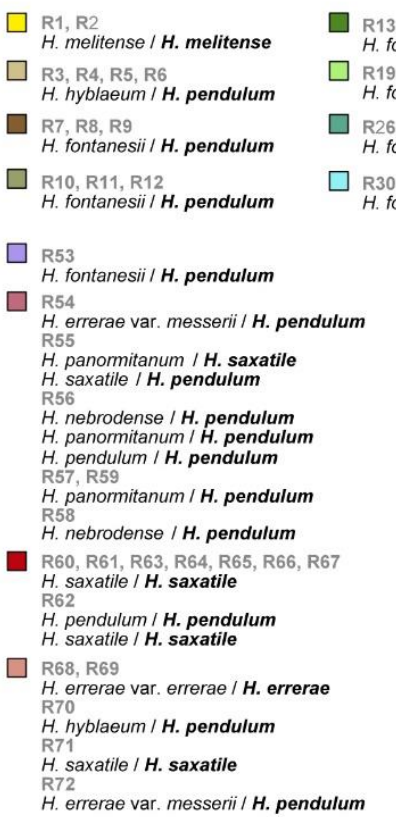

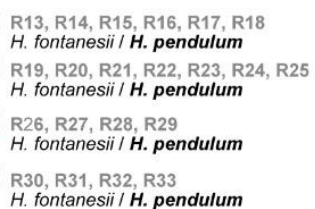

fontanesiil $H$. pendulum

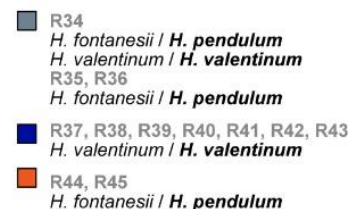

$\square$ R46 H. panormitanum/ H. pendulum

$\square$ R47, R48

H. boissieri / H. pendulum

$H$. valentinum / $\boldsymbol{H}$. valentinum

$\square$ R51, R52

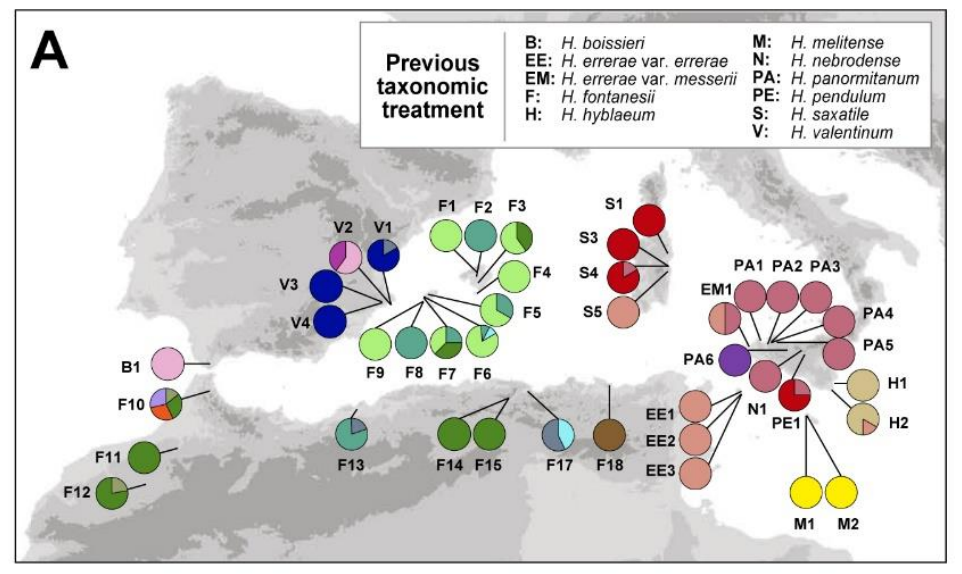

\section{B}

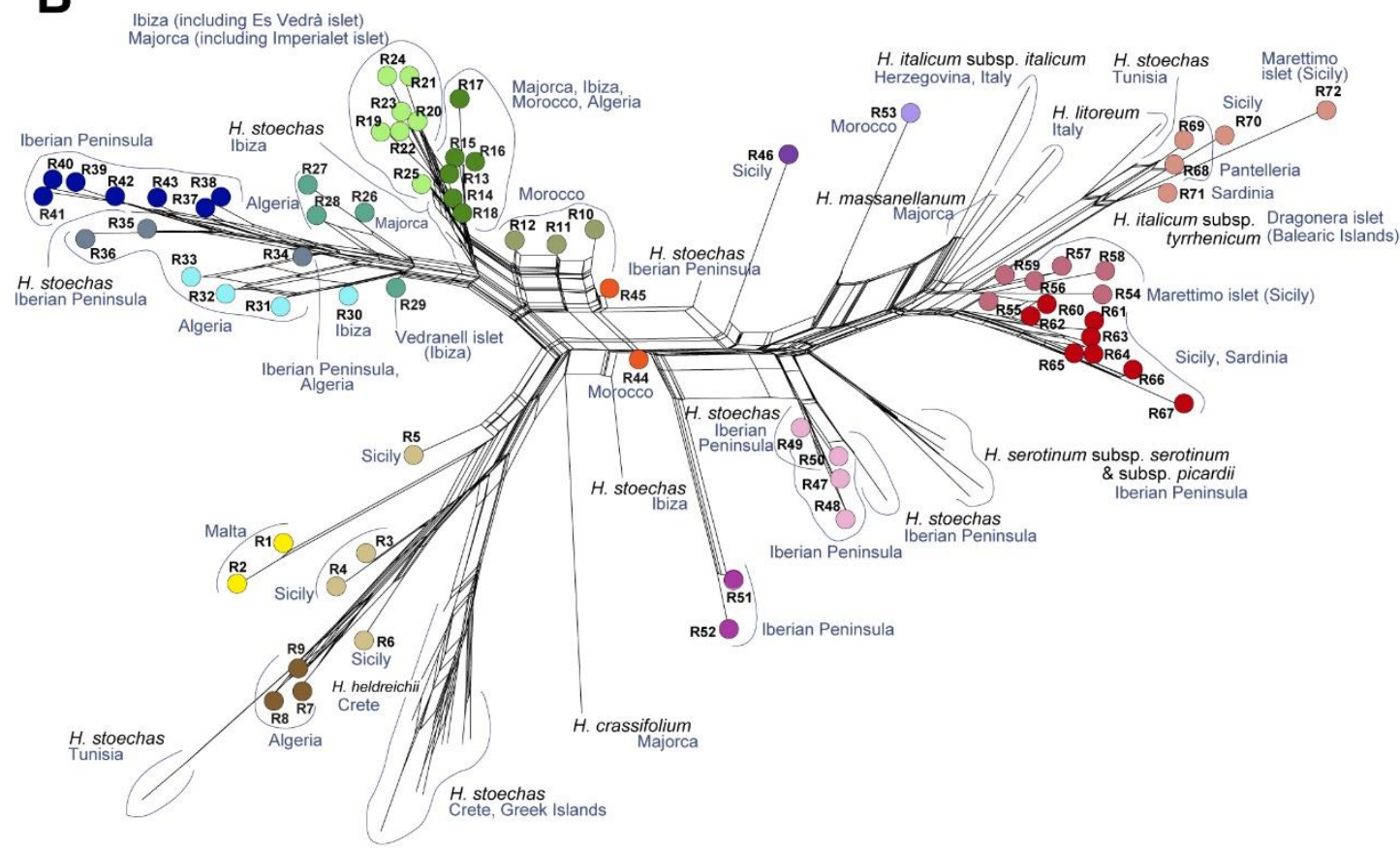

Fig. 2. A, Geographic distribution of the 72 different ribotypes found in 159 individuals from 42 populations of the $H$. pendulum complex. To simplify the representation of the ribotypes, they have been reduced to 18 colour groups (see text for details). B, Neighbour-Net graph derived from the 72 ribotypes detected in the H. pendulum complex and 38 ribotypes detected in other taxa of sect. Stoechadina (see text for details) Geographical origin in blue. For population abbreviation codes and the specimens containing each ribotype see Electr. Suppl.: Table S1. 


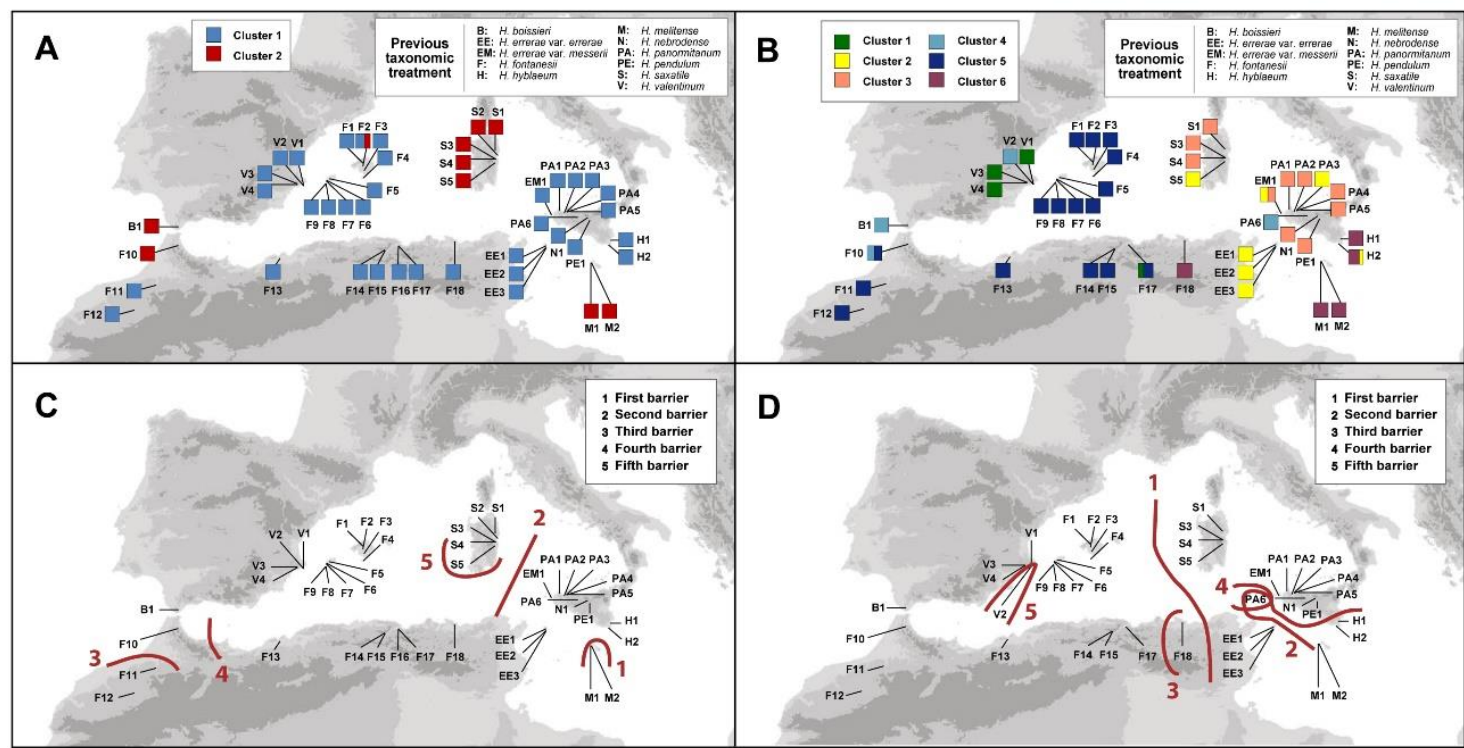

Fig. 3. A-B, BAPS analysis of the $H$. pendulum complex. A, using cpDNA sequences $(K=2)$. B, using nrDNA sequences $(K=6)$. C-D, The first five barriers detected in the $H$. pendulum complex using Monmonier's maximum difference algorithm with Nei's genetic distances. C, from the cpDNA sequences. D, from the nrDNA.
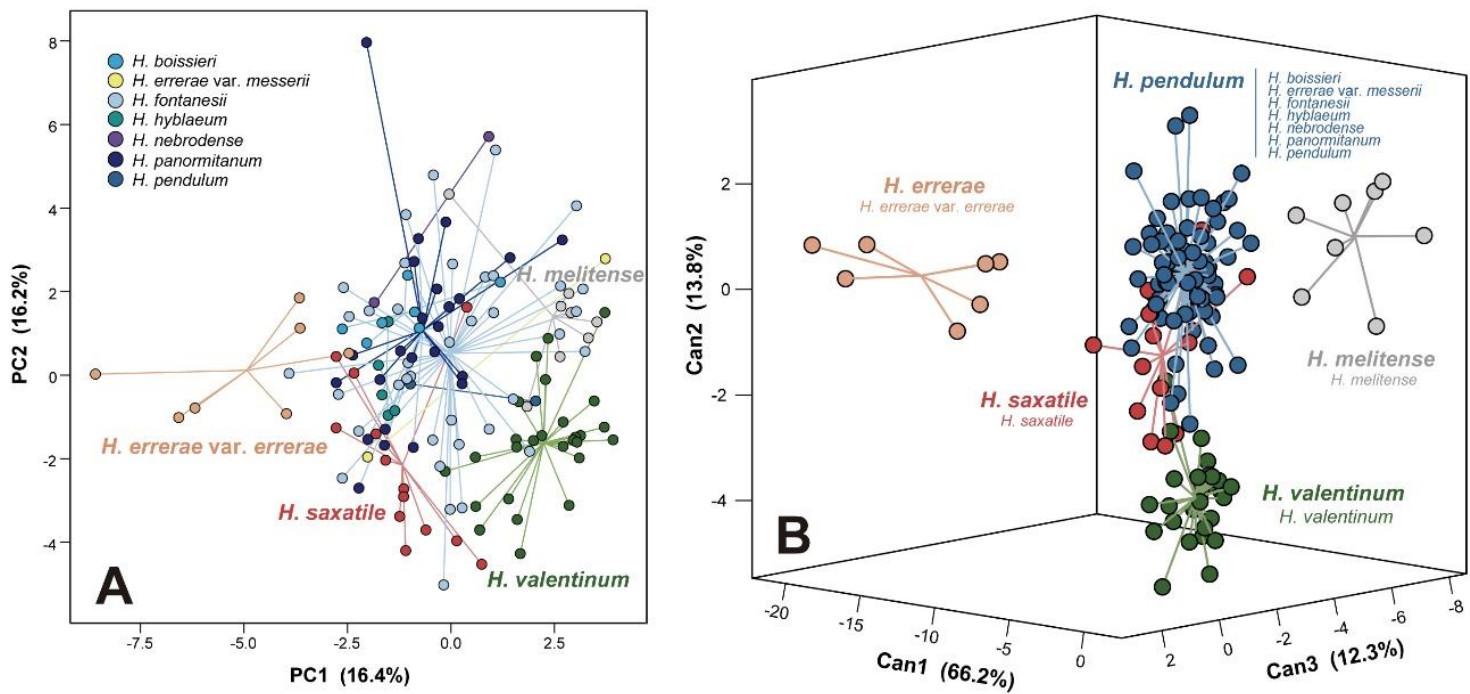

Fig. 4. A, Scatterplot of the first two axes from the Principal Component Analysis (PCA3) based on 31 morphological characters studied in 136 individuals: 7 individuals of $\mathrm{H}$. boissieri, 7 of $\mathrm{H}$. errerae var. errerae, 2 of $H$. errerae var. messerii, 38 of $H$. fontanesii, 5 of $H$. hyblaeum, 8 of $H$. melitense, 2 of $H$. nebrodense, 24 of $H$. panormitanum, 2 of $H$. pendulum, 13 of $H$. saxatile and 28 of $H$. valentinum. Taxa are labelled following previous taxonomic treatments (see text for details). B, Scatterplot of the Canonical Discriminant Analysis (CDA) based on 29 morphometric variables for the 136 individuals classified in five predefined groups, the final taxonomic treatment, considering molecular and morphological data: $H$. errerae, $H$. melitense, $H$. pendulum, $H$. saxatile and $H$. valentinum. Previous taxonomic treatment and final taxonomic treatment (in bold) are given. 

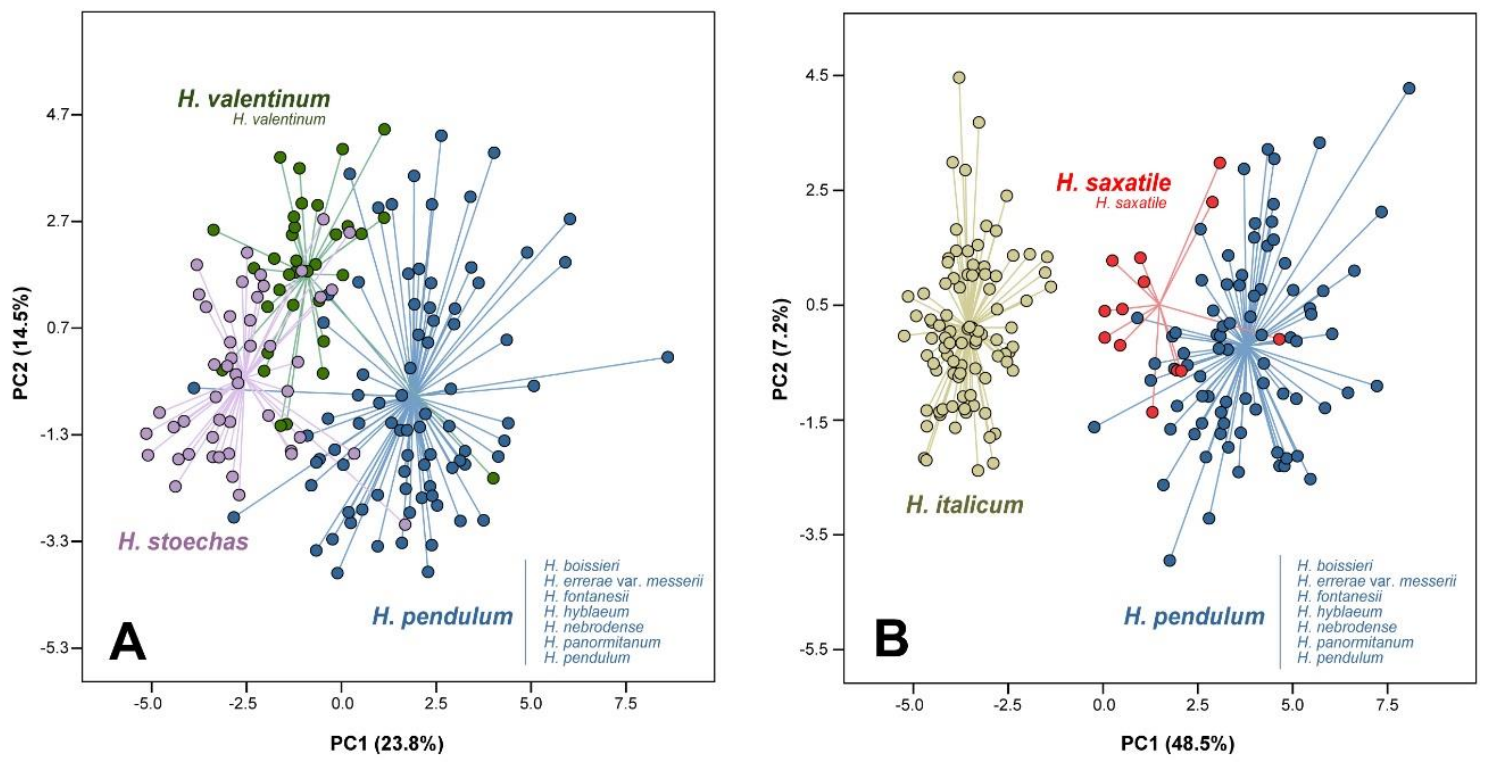

Fig. 5. A, Scatterplot of the first two axes from the Principal Component Analysis (PCA4) based on 29 morphological characters studied for a total of 156 individuals: 28 individuals of $H$. valentinum, 80 of $H$. pendulum and 48 of $\mathrm{H}$. stoechas. Previous taxonomic treatment and final taxonomic treatment (in bold) are indicated. B, Scatterplot of the first two axes from the Principal Component Analysis (PCA5) based on 29 morphological characters studied for a total of 183 individuals: 13 individuals of $H$. saxatile, 80 of $H$. pendulum and 90 of $H$. italicum. Previous taxonomic treatment and final taxonomic treatment (in bold) are indicated. 


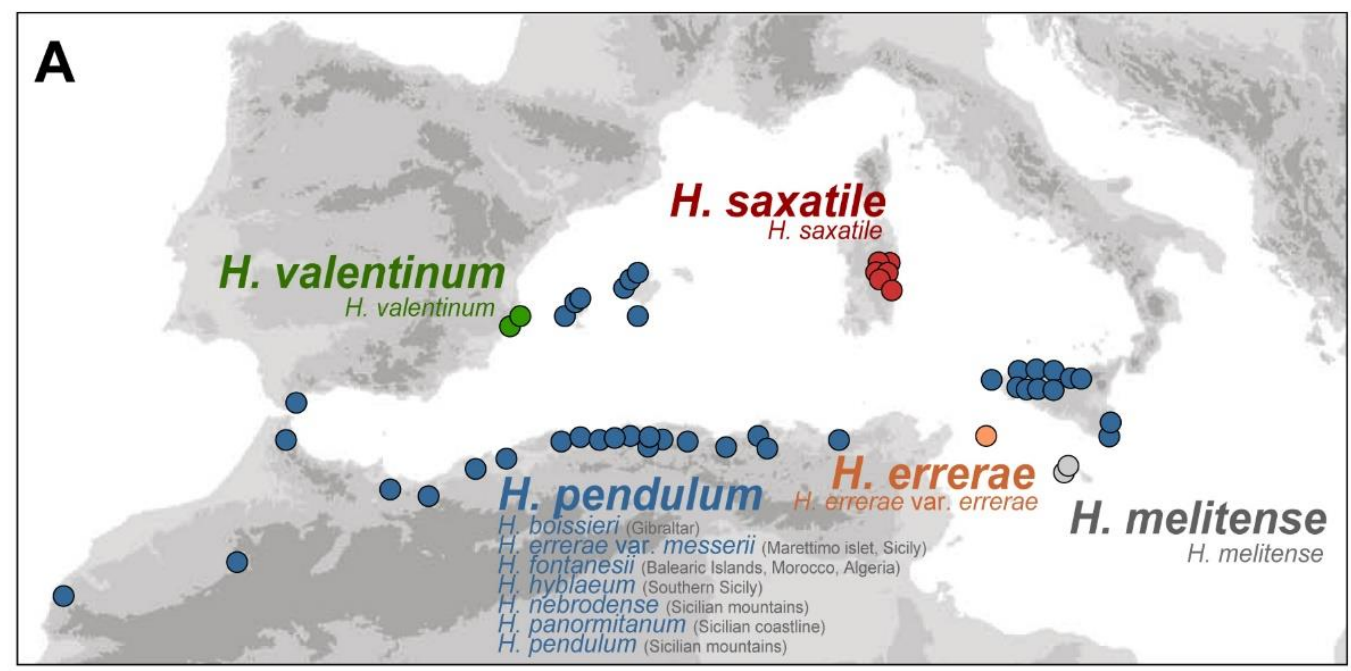

B H. pendulum

H. errerae

H. melitense

H. saxatile

H. valentinum
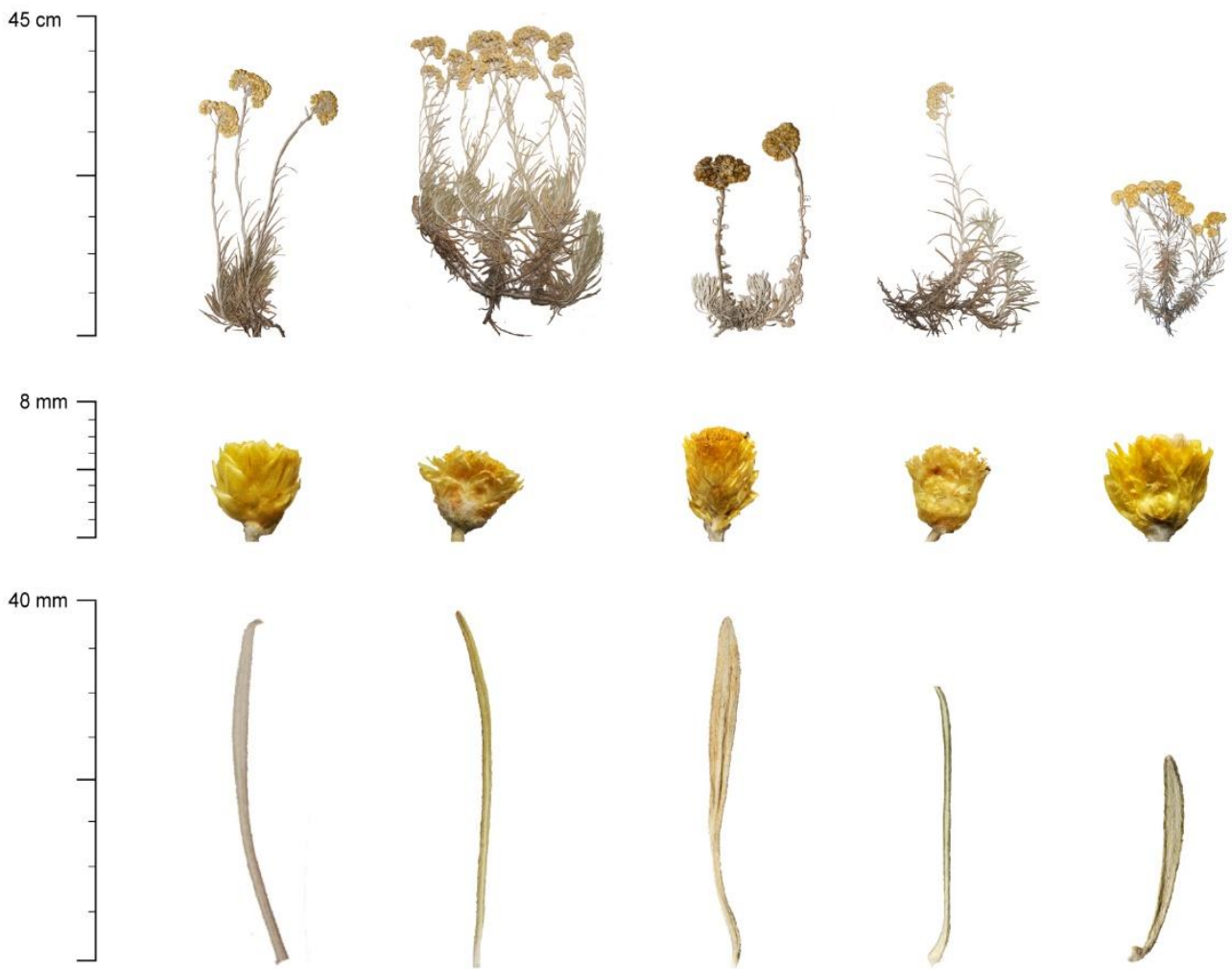

Fig. 6. A, Distribution area of the species of the H. pendulum complex recognised in this study. Previous taxonomic treatment and final taxonomic treatment (in bold) are indicated. B, Details of general appearance, capitula and leaves of each taxon finally recognized. 